Research Square
Preprints are preliminary reports that have not undergone peer review.

They should not be considered conclusive, used to inform clinical practice, or referenced by the media as validated information.

\title{
Geochemical and statistical evaluation of groundwater in the Thamirabarani river basin, south India
}

\author{
Gajendran Chellaiah \\ Karunya Institute of technology and Science: Karunya Institute of Technology and Sciences \\ Basker \\ Karunya Institute of technology and Science: Karunya Institute of Technology and Sciences \\ Hima Pravin \\ Karunya Institute of technology and Science: Karunya Institute of Technology and Sciences \\ Suneel Kumar Joshi \\ National Institute of Hydrology \\ Sneha Gautam ( $\nabla$ snehagautam@karunya.edu ) \\ Karunya Institute of technology and Science: Karunya Institute of Technology and Sciences
}

\section{Research Article}

Keywords: Groundwater quality, Hydrogeochemistry, Irrigation, Principal Component Analysis, Tamil Nadu

Posted Date: March 1st, 2021

DOI: https://doi.org/10.21203/rs.3.rs-163816/v1

License: @ (i) This work is licensed under a Creative Commons Attribution 4.0 International License. Read Full License 


\section{Abstract}

In the present study, an attempt has been made to develop the dictate metrics using a multi-proxy approach, i.e., spatial-temporal analysis, statistical evaluation, and hydrogeochemical analysis for 45 water samples located in the Thamirabarani river basin in Tamil Nadu, India. In order to evaluate the aptness of developed metrics for agriculture and domestic needs, eleven years dataset was analyzed and compared with national and international standards. Monitoring and analysis results revealed that the concentration of calcium and chloride ion was on the higher side in all the selected locations. These higher values may be attributed to the regional point sources such as untreated water disposal and off-peak sources such as agriculture practices. The principal component analysis resulted in $84.2 \%$ of the total variance in the post-monsoon season dataset. The major analyzed cations and anions were observed in the following order: $\mathrm{Na}^{+}>\mathrm{Ca}^{2+}>\mathrm{Mg}^{2+}>\mathrm{K}^{+}$and $\mathrm{Cl}^{-}>\mathrm{HCO}_{3}{ }^{-}>\mathrm{SO}_{4}{ }^{2-}>\mathrm{NO}_{3}{ }^{-}$, respectively. Overall, this study revealed that the studied area's groundwater quality was significantly affected by the high salinity in the region, probably due to anthropogenic activities and unprotected river sites.

\section{Introduction}

Water is one of the most vital components of the environment and is considered a major lifeline of humans and society. Further, being an inevitable part of the ecosystem and flora-fauna, water plays an essential role in the survival of soil, water, and air environment associated micro-organisms (Kisi and Ay, 2014). Such concerns undoubtedly suggest that water quality and quantity are crucial in ensuring the earth's environment's sustainability living and non-living entities. The condition of water quality in developing countries is also not untouched by regional activities (both natural and anthropogenic), ultimately resulting in deteriorated water resources (Zhou et al., 2013). Having this background understanding, groundwater quality analysis becomes of utmost importance to ensure its utility for urban and rural activities (Anandakumar et al., 2009). Such water scarcities issues were also raised in 1992 in Rio de Janeiro during the U.N. Conference on Environment and Development. Later in 2017, the water wastage issues were discussed by U.N. member nations, emphasizing drinking water scarcity worldwide (Sujatha, 2017). Moreover, the groundwater levels are also declining (Sinha et al., 2019; Shekhar et al., 2020), and the increasing rate of deterioration of the water quality (Sajitha and Vijayamma, 2016).

Nowadays, water qualitative and quantitative concerns for water resources are growing worldwide, especially in Asian countries like China, India, Bangladesh. Among these countries, water contamination in Indian states is a severe concern, depending on different pollutants (microbial, organic and inorganic). In addition to this, India also faces frequent issues of floods and droughts, which also increases groundwater pollution (Thillai Arasu et al., 2007). The groundwater quality is also affected by anthropogenic activities (i.e., waste disposal and agricultural waste) and natural processes (mineral dissolution and geochemical reactions). This ultimately led to less per capita water availability in India ( Joarder et al., 2008; Kumar, 2013).

On the other side, water supply demands for drinking, household activities, agriculture and industrial purposes are significantly based on groundwater sources (Joarder et al., 2008). In this context, the quality indices can be derived using anions and cations elements for any given basin (Saeedi et al., 2010). A detailed assessment of various usage patterns of groundwater quantitative and qualitative determination of water resources (physical, chemical and biological) plays an essential role (Selvakumar et al., 2017). Among all characteristic's types, chemical characteristics of groundwater are affected by anthropogenic activities and are well documented for developing countries like India, China, Bangladesh. However, the attention paid to these concerns is minimal, and water resources management needs urgent action, especially in semi-arid and arid regions (Alaa et al., 2016).

Bearing these considerations in mind, the present study aimed to analyze groundwater by using multi-proxy approaches (spatial-temporal analysis, statistical evaluation, and hydro-geochemical analysis) for the impact prediction of groundwater pollutants around the Tamirabarani river basin.

\section{Study Area And Methodology}

A mixture of waste chemicals, leachate, and groundwater are usually in solution form, but other insoluble forms are possible. One such groundwater quality analysis for Tamirabharani River has been analyzed and interpreted using AquaChem, AqQA, Time Trend and ArcGIS environment. The parameters like Ca, Mg, $\mathrm{Na}, \mathrm{K}, \mathrm{HCO}_{3}, \mathrm{CO}_{3}, \mathrm{SO}_{4}, \mathrm{Cl}, \mathrm{NO}_{4}, \mathrm{pH}, \mathrm{EC}$, and TDS from 45 sampling locations were analyzed for pre- and post-monsoon seasons during 2016 and 2017 . In the present study, we have compiled historical data from 1995 to 2007 from Tamilnadu Public Work Department Data Centre. Here, in the present study, we prepared time-series, Durov, Piper, Box and Whisker, Scatter, Stiff, Schoeller, Wilcox, Cross, lon balance diagram, Radial and Pie diagram based on geochemical parameters.

\subsection{Study Area}

The focus area is the Thamirabarani river basin, located in Tamil Nadu in India (Fig. 1). The geographical extent of the study area is from $8^{\circ} 8 \otimes \mathrm{N}$ to $9^{\circ} 23 \square \mathrm{N}$ latitude and from $77^{\circ} 09 \otimes \mathrm{E}$ to $77^{\circ} 54 \mathrm{E}$ longitude and covers an area of about $5665 \mathrm{~km}^{2}$. The climate condition of the study area is considered a semi-arid region. The annual rainfall of the study area is about $680 \mathrm{~mm}$. The Thamirabarani River is perennial in the study area, which is a major source for irrigation practices.

\subsection{Sampling and analysis}

The water samples were collected from 45 locations in the study area during pre- and post-monsoon seasons from 2016 to 2017 (Fig. 1). Also, we compiled historical water quality data from 1995 to 2006 from Tamilnadu Public Work Department Data Centre. The water samples were collected from bore wells and dug wells located within the study area and analyzed for water quality parameters ( $\mathrm{pH}, \mathrm{EC}, \mathrm{TDS}, \mathrm{Ca}^{2+}, \mathrm{Mg}^{2+}, \mathrm{Na}^{+}, \mathrm{K}^{+}, \mathrm{Cl}^{-}, \mathrm{HCO}_{3}{ }^{-}, \mathrm{CO}_{3}, \mathrm{SO}_{4}{ }^{2-}, \mathrm{and} \mathrm{NO}_{3}{ }^{-}$). The standards methods (APHA, 1999) were used for the sampling and analysis of collected data. Determination of hydro-geochemical facies provides sufficient information on the aroundwater svstem's chemical water quality (Kumar, 2013). The hydro-geo-chemical analysis has carried out using AqQA software. Trend Loading [MathJax]/jax/output/CommonHTML/jax.js 
analysis was carried out for the identified sample locations to know the temporal pattern of groundwater quality (Jones et al., 2013; Jones et al., 2015) in the study area. Principal Component Analysis (PCA) was used to identify the actual status of physio-chemical parameters in collected samples. This method helps in extracting different factors to identify the predominant variable using factor analysis. In PCA, to extract factors, the varimax rotation has been used. PCA technique is used to reduce the data, and it will suggest how many varieties are essential to explain the observed variance in the data. Statistically, the correlation between the statistical variable analyses performed on the physico-chemical parameters.

\section{Results And Discussion}

The descriptive statistical analysis of groundwater quality data collected during pre-and post-monsoon seasons is shown in Table 1. It observed that out of 45 sample points, a higher mean concentration of conductivity has recorded. Some wells exceed for calcium and magnesium hardness, respectively. The permissible limit for $\mathrm{Cl}^{-}, \mathrm{SO}_{4}{ }^{2-}, \mathrm{HCO}_{3}{ }^{-}$, and $\mathrm{NO}_{3}{ }^{-}$have violated $100 \%$ of the samples. The chemical composition of collected data sets have been analyzed statistically, and a comparison has been made with international standards (Table 1). The observed results indicated the alkaline nature of groundwater quality with $\mathrm{pH}$ ranging between 7.2 and 8.4 .

The electrical conductivity $(\mathrm{EC})$ values of water samples; the observed results vary from $1324 \mu \mathrm{S} / \mathrm{cm}$ to $2374 \mu \mathrm{S} / \mathrm{cm}$, indicating higher salinity and dissolved ionic concentration. Reported values $(5000 \mathrm{mg} / \mathrm{l}$ ) of TDS during sampling have been higher than the international standards (WHO; $1000 \mathrm{mg} / \mathrm{l}$ ) for drinking the maximum allowable TDS values. The higher values of TDS have been observed due to the percolation of channel water containing solids, agricultural wastes, and industrial seepages through the country rocks (Offor et al., 2015). The reported higher concentration values $236 \mathrm{mg} / \mathrm{l}, 429 \mathrm{mg} / \mathrm{l}, 1018 \mathrm{mg} / \mathrm{l}, 106$ $\mathrm{mg} / \mathrm{l}$ for $\mathrm{Ca}^{2+}, \mathrm{Mg}^{2+}, \mathrm{Na}^{+}$, and $\mathrm{K}^{+}$ions, respectively. According to cation concentration, the sequence has been arranged; $\mathrm{Ca}^{2+}>\mathrm{Mg}^{2+}>\mathrm{Na}^{+}>\mathrm{K}^{+}$. This study's outcomes highlighted that most of the samples (approximately more than 70\%) are beyond the permissible limits, like 200, 150, 200, and $12 \mathrm{mg} / \mathrm{l}$, for $\mathrm{Ca}^{2+}$, $\mathrm{Mg}^{2+}, \mathrm{Na}^{+}, \mathrm{K}^{+}$, respectively.

Table 1

Summary of statistics of water samples collected during the present study

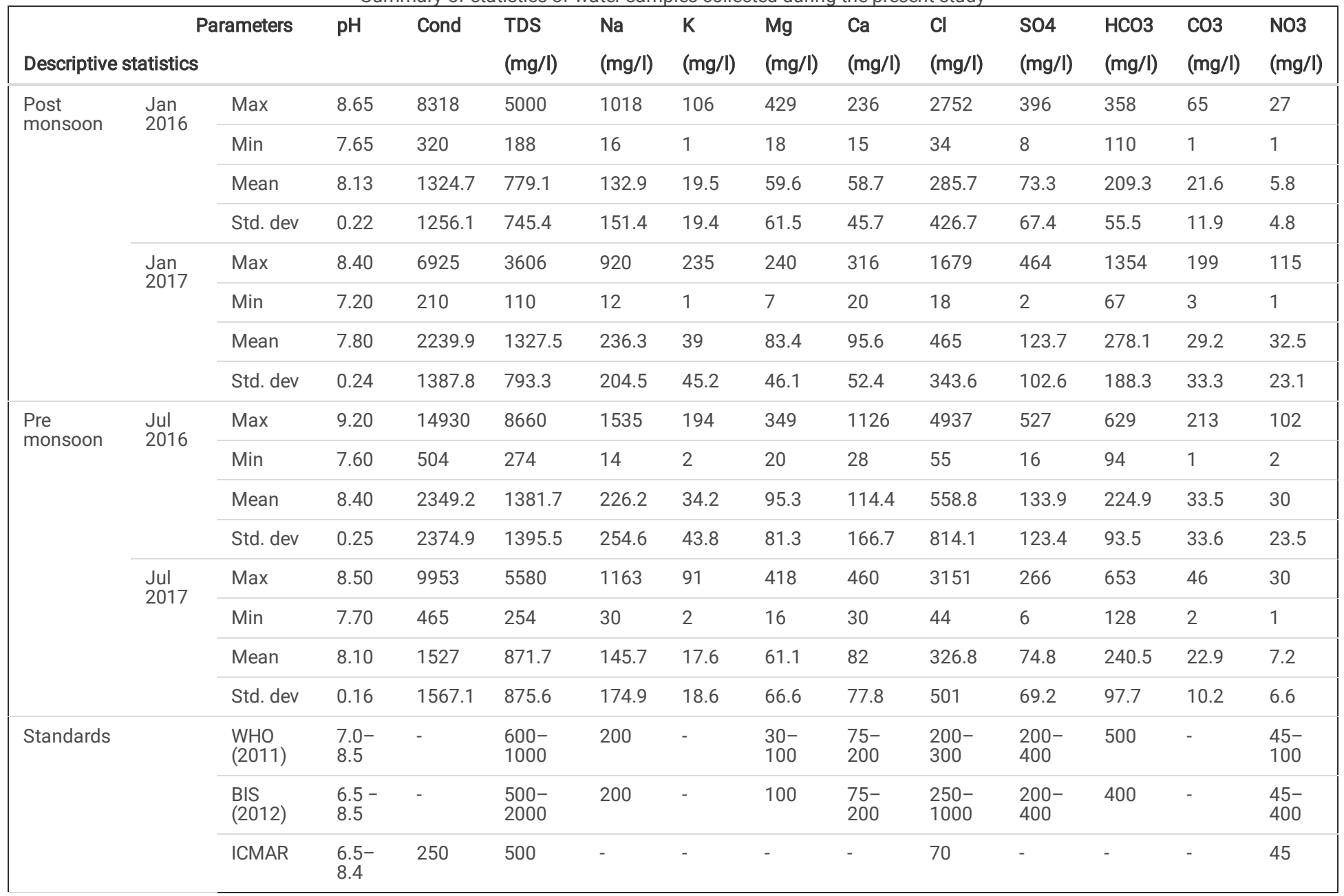

\subsection{Correlation Analysis}

The correlation coefficient is generally used in evaluating the relationship between two variables. Pearson's correlation analysis applied to the post-monsoon Loading [MathJax]/jax/output/CommonHTML/jax.js (July 2016 and 2017) presented in Tables 2 and 3 show the correlation coefficient between the major ions in the 
study area. Suppose the values of the correlation coefficient ' $r$ ' between the variable are large. In that case, it implies the two variables are highly correlated; in such case, it gets split to linear relation $Y=A x+B$ (Gajendran and Thamarai, 2008).

$$
r=\frac{(X-\bar{X})(Y-\bar{Y})}{\sqrt{ }\left((X-\bar{X})^{2}(Y-\bar{Y})^{2}\right)}
$$

The value of ' $r$ ' in positive correlation lies between 0 to 0.99 (Gajendran et al., 2013). A significant positive correlation among various indicators was evident. Conductivity has a significant correlation with TDS, $\mathrm{Na}^{+}, \mathrm{K}^{+}, \mathrm{Mg}^{2+}, \mathrm{Ca}^{2+}, \mathrm{Cl}^{-}$, and $\mathrm{SO}_{4}{ }^{2-}$ with $r=0.67$ to 0.98 in post-monsoon. Correlation in post-monsoon has

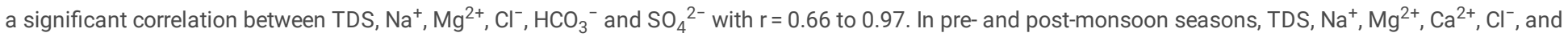
$\mathrm{SO}_{4}{ }^{2-}$ with $r=0.79$ to 0.99 and $r=0.61$ to 0.99 , respectively.

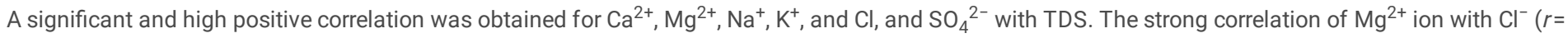
0.966). The variation of these relationships indicates the entanglement of the groundwater's hydro-chemical components, where natural water always contains dissolved and suspended substances of minerals. The source of $\mathrm{Mg}^{2+}$ and $\mathrm{Na}^{+}$in the groundwater was the ion exchange of minerals between rocks and water. $\mathrm{NO}_{3}{ }^{-}$ion positively high correlated with $\mathrm{Cl}^{-}(r=0.67)$, which indicates the contamination from septic systems, fertilizers, municipal wastewaters, and sometimes the cultivation of grasslands.

Table 2

Pearson's correlation of groundwater quality for post-monsoon.

\begin{tabular}{|c|c|c|c|c|c|c|c|c|c|c|c|c|c|c|c|c|c|}
\hline Januar & 2016 & & & & & & & & & & & & & uary 20 & & & \\
\hline & $\mathrm{pH}$ & Cond & TDS & $\mathrm{Na}$ & $\mathrm{K}$ & $\mathrm{Mg}$ & $\mathrm{Ca}$ & $\mathrm{Cl}$ & SO4 & $\mathrm{HCO} 3$ & $\mathrm{CO} 3$ & NO3 & & $\mathrm{pH}$ & Cond & TDS & $\mathrm{N}$ \\
\hline $\mathrm{pH}$ & 1 & & & & & & & & & & & & $\mathrm{pH}$ & 1 & & & \\
\hline Cond & -.048 & 1 & & & & & & & & & & & Cond & 0.124 & 1 & & \\
\hline TDS & -.037 & 0.998 & 1 & & & & & & & & & & TDS & 0.174 & 0.977 & 1 & \\
\hline $\mathrm{Na}$ & .006 & 0.979 & 0.985 & 1 & & & & & & & & & $\mathrm{Na}$ & 0.217 & 0.944 & 0.932 & 1 \\
\hline $\mathrm{K}$ & .239 & 0.733 & 0.746 & 0.746 & 1 & & & & & & & & $\mathrm{~K}$ & 0.261 & 0.438 & 0.518 & 0. \\
\hline $\mathrm{Mg}$ & .022 & 0.966 & 0.969 & 0.956 & 0.700 & 1 & & & & & & & $\mathrm{Mg}$ & 0.116 & 0.740 & 0.786 & 0. \\
\hline $\mathrm{Ca}$ & -.323 & 0.670 & 0.653 & 0.549 & 0.380 & 0.512 & 1 & & & & & & $\mathrm{Ca}$ & -0.14 & 0.569 & 0.583 & 0. \\
\hline $\mathrm{Cl}$ & -.023 & 0.991 & 0.992 & 0.977 & 0.719 & 0.966 & 0.654 & 1 & & & & & $\mathrm{Cl}$ & 0.167 & 0.901 & 0.953 & 0. \\
\hline SO4 & -.089 & 0.871 & 0.877 & 0.859 & 0.705 & 0.859 & 0.497 & 0.822 & 1 & & & & SO4 & 0.145 & 0.878 & 0.860 & 0. \\
\hline $\mathrm{HCO} 3$ & -.167 & 0.174 & 0.165 & 0.183 & 0.178 & 0.150 & 0.066 & 0.089 & 0.210 & 1 & & & $\mathrm{HCO} 3$ & 0.034 & 0.665 & 0.530 & 0. \\
\hline $\mathrm{CO} 3$ & .464 & 0.549 & 0.562 & 0.586 & 0.647 & 0.590 & 0.081 & 0.524 & 0.559 & 0.204 & 1 & & $\mathrm{CO} 3$ & -0.12 & 0.127 & 0.126 & 0. \\
\hline NO3 & -.204 & 0.279 & 0.275 & 0.212 & 0.182 & 0.214 & 0.351 & 0.202 & 0.488 & -0.022 & 0.173 & 1 & NO3 & 0.073 & 0.407 & 0.501 & 0. \\
\hline
\end{tabular}

Bold values indicates good correlation $(r>=0.60)$ 
Table 3

Pearson's correlation of groundwater quality for pre monsoon.

\begin{tabular}{|c|c|c|c|c|c|c|c|c|c|c|c|c|c|c|c|c|c|c|}
\hline \multicolumn{9}{|c|}{ July 2016} & \multicolumn{10}{|c|}{ July 2017} \\
\hline & $\mathrm{pH}$ & Cond & TDS & $\mathrm{Na}$ & $\mathrm{K}$ & $\mathrm{Mg}$ & $\mathrm{Ca}$ & $\mathrm{Cl}$ & SO4 & $\mathrm{HCO} 3$ & $\mathrm{CO} 3$ & NO3 & & $\mathrm{pH}$ & Cond & TDS & $\mathrm{Na}$ & $\mathrm{K}$ \\
\hline $\mathrm{pH}$ & 1 & & & & & & & & & & & & $\mathrm{pH}$ & 1 & & & & \\
\hline Cond & -0.25 & 1 & & & & & & & & & & & Cond & 0.008 & 1 & & & \\
\hline TDS & -0.26 & 0.99 & 1 & & & & & & & & & & TDS & 0.017 & 0.999 & 1 & & \\
\hline $\mathrm{Na}$ & -0.13 & 0.95 & 0.95 & 1 & & & & & & & & & $\mathrm{Na}$ & 0.132 & 0.938 & 0.944 & 1 & \\
\hline K & -0.08 & 0.33 & 0.35 & 0.36 & 1 & & & & & & & & $\mathrm{~K}$ & 0.195 & 0.617 & 0.622 & 0.653 & 1 \\
\hline $\mathrm{Mg}$ & -0.39 & 0.85 & 0.86 & 0.71 & 0.43 & 1 & & & & & & & $\mathrm{Mg}$ & -0.03 & 0.984 & 0.980 & 0.889 & 0.57 \\
\hline $\mathrm{Ca}$ & -0.26 & 0.91 & 0.90 & 0.81 & 0.03 & 0.70 & 1 & & & & & & $\mathrm{Ca}$ & -0.17 & 0.819 & 0.812 & 0.590 & 0.30 \\
\hline $\mathrm{Cl}$ & -0.25 & 0.98 & 0.97 & 0.92 & 0.28 & 0.85 & 0.91 & 1 & & & & & $\mathrm{Cl}$ & 0.01 & 0.991 & 0.988 & 0.936 & 0.58 \\
\hline SO4 & -0.27 & 0.79 & 0.80 & 0.71 & 0.41 & 0.83 & 0.65 & 0.74 & 1 & & & & SO4 & -0.05 & 0.729 & 0.745 & 0.601 & 0.41 \\
\hline $\mathrm{HCO} 3$ & -0.05 & 0.22 & 0.24 & 0.30 & 0.25 & 0.20 & 0.06 & 0.12 & 0.36 & 1 & & & $\mathrm{HCO} 3$ & 0.100 & 0.364 & 0.372 & 0.410 & 0.32 \\
\hline $\mathrm{CO} 3$ & -0.18 & 0.56 & 0.56 & 0.46 & 0.25 & 0.68 & 0.46 & 0.62 & 0.55 & 0.273 & 1 & & $\mathrm{CO} 3$ & 0.427 & 0.259 & 0.272 & 0.351 & 0.44 \\
\hline NO3 & -0.40 & 0.31 & 0.34 & 0.16 & 0.39 & 0.60 & 0.19 & 0.28 & 0.48 & 0.222 & 0.47 & 1 & NO3 & -.091 & 0.169 & 0.184 & 0.093 & 0.33 \\
\hline
\end{tabular}

\subsection{Principal Component Analysis (PCA)}

In this study, a statistical tool (PCA) has been used for collected 45 water samples to assess the relationship between hydro-chemical composition and available factor/physio chemical parameters to identify the actual status of water quality. The PCA results (i.e., Eigen values, percentage of the total variance, etc.) is summarized in Table 4.

Table 4

Factor analysis scores (Varimax rotation) of various physicochemical parameters in the study area:

\begin{tabular}{|c|c|c|c|c|c|c|c|c|c|c|c|c|c|}
\hline \multicolumn{14}{|l|}{ Factor analysis } \\
\hline \multirow[t]{2}{*}{ Parameter } & \multicolumn{3}{|c|}{ January 2016} & \multicolumn{4}{|c|}{ January 2017} & \multicolumn{3}{|c|}{ July 2016} & \multicolumn{3}{|c|}{ July 2017} \\
\hline & 1 & 2 & 3 & 1 & 2 & 3 & 4 & 1 & 2 & 3 & 1 & 2 & 3 \\
\hline $\mathrm{pH}$ & 0.094 & -0.892 & -0.213 & 0.040 & -0.08 & 0.890 & -0.07 & -0.15 & -0.81 & 0.176 & -0.19 & 0.731 & -0.133 \\
\hline Cond & 0.977 & 0.157 & 0.023 & 0.904 & 0.383 & 0.123 & 0.089 & 0.967 & 0.160 & 0.181 & 0.979 & 0.168 & 0.091 \\
\hline TDS & 0.982 & 0.138 & 0.018 & 0.822 & 0.499 & 0.223 & 0.116 & 0.958 & 0.169 & 0.205 & 0.975 & 0.182 & 0.107 \\
\hline $\mathrm{Na}$ & 0.970 & 0.058 & 0.060 & 0.882 & 0.221 & 0.222 & 0.144 & 0.929 & -0.04 & 0.250 & 0.887 & 0.347 & -0.011 \\
\hline K & 0.823 & -0.224 & 0.061 & 0.355 & 0.256 & 0.563 & -0.05 & 0.154 & 0.198 & 0.711 & 0.513 & 0.519 & 0.296 \\
\hline $\mathrm{Mg}$ & 0.958 & 0.040 & 0.029 & 0.529 & 0.539 & 0.218 & 0.424 & 0.752 & 0.500 & 0.305 & 0.972 & 0.104 & 0.112 \\
\hline $\mathrm{Ca}$ & 0.584 & 0.582 & -0.111 & 0.383 & 0.749 & -0.24 & -0.28 & 0.948 & 0.120 & -0.17 & 0.861 & -0.16 & 0.197 \\
\hline $\mathrm{Cl}$ & 0.964 & 0.125 & -0.035 & 0.682 & 0.568 & 0.266 & 0.172 & 0.971 & 0.173 & 0.096 & 0.979 & 0.118 & 0.015 \\
\hline SO4 & 0.897 & 0.168 & 0.032 & 0.865 & 0.272 & 0.129 & 0.019 & 0.710 & 0.317 & 0.421 & 0.705 & 0.058 & 0.552 \\
\hline $\mathrm{HCO} 3$ & 0.162 & 0.071 & 0.942 & 0.875 & -0.27 & -0.08 & -0.07 & 0.106 & -0.09 & 0.771 & 0.321 & 0.556 & -0.058 \\
\hline $\mathrm{CO} 3$ & 0.683 & -0.529 & 0.098 & 0.081 & -0.01 & -0.13 & 0.946 & 0.503 & 0.368 & 0.362 & 0.096 & 0.842 & 0.254 \\
\hline NO3 & 0.308 & 0.419 & -0.306 & 0.051 & .0868 & 0.109 & 0.078 & 0.115 & 0.778 & 0.427 & 0.066 & 0.024 & 0.972 \\
\hline Eigen values & 7.126 & 1.739 & 1.060 & 4.813 & 2.594 & 1.454 & 1.247 & 5.953 & 1.899 & 1.874 & 6.229 & 2.059 & 1.495 \\
\hline$\%$ of varience & 59.38 & 14.48 & 8.834 & 40.10 & 21.61 & 12.11 & 10.39 & 49.60 & 15.82 & 15.61 & 51.91 & 17.15 & 12.45 \\
\hline Cumulative \% & 59.385 & 73.873 & 82.707 & 40.10 & 61.7 & 73.8 & 84.2 & 49.6 & 65.4 & 81.4 & 51.9 & 69.6 & 81.5 \\
\hline
\end{tabular}


used this technique to interpret the groundwater quality (Hotelling, 1933; Helsel and Hirsch, 2002; Mcbride, 2005; Visser et al., 2009; Belkhiri et al., 2010; Kim and Chung, 2011; Bhat et al., 2014). For Factor I, 59\% (pre-monsoon) and 40\% (post-monsoon) of the total variance showing strong positive loadings on EC, TDS, $\mathrm{Mg}^{2+}, \mathrm{Na}^{+}, \mathrm{K}^{+}, \mathrm{CO}_{3}$ as well as $\mathrm{Cl}^{-}$and $\mathrm{SO}_{4}{ }^{2-}$, which indicating significant interference of anthropogenic activities in mineral water reaction. On the other hand, $14 \%, 8.83 \%$ of the total variance has been observed for Factor II and Factor III, respectively. The results from the PCA suggested that the set of natural soluble salts explains most of the variations.

\subsection{Time-series Analysis}

Two kinds of approaches have been developed to predict water quality parameters. One is time-series prediction, while the other predicts the water quality parameters without considering the time head (Guoyin and Zhang, 2015). Time-series analysis is a forecasting method used to predict future value based on the previously observed value (Deng and Wang, 2017; Conrads et al., 2007; Sun and Koch, 1996; Ragavan and Fernandez, 2010; Faruk, 2010; Akkaraboyina and Raju, 2012; Mirsanjari and Mohammadyari, 2018). The water samples collected from 45 sampling stations with various water quality parameters like pH, $\mathrm{EC}, \mathrm{TDS}, \mathrm{Ca}^{2+}, \mathrm{Mg}^{2+}, \mathrm{Na}^{+}, \mathrm{K}^{+}, \mathrm{Cl}^{-}, \mathrm{HCO}_{3}{ }^{-}, \mathrm{CO}_{3}, \mathrm{SO}_{4}{ }^{2-}$, and $\mathrm{NO}_{3}{ }^{-}$. TDS in post and pre-monsoon (Jul 2016 and 2017) of station number TM-240, $\mathrm{TM}^{-244}, \mathrm{TM}-54$, and TM-295 have loaded with a high concentration of TDS (Fig. 2).

\subsection{Hydro-geochemical Analysis}

To understand the hydro-geo-chemical evolution of groundwater in the study area, we are determined by plotting various diagrams such as lon balance diagram, Piper Trilinear, Durov plot, scatter plot, Wilcox plot, Cross plot, Pie diagram, Radial plot, Stiff diagram and Schoeller diagram. The overall checking of the cation-anion balance in the sample is to validate the water test results. If the analysis is accurate, then the sum of milliequivalents of cations and anions should be nearly equal (Srinivasamoorthy et al., 2011; Xiao et al., 2016). More than $5 \%$ of the cation-anion balance error might imply that the analysis is not accurate. The accuracy is calculated by the ion balance errors, generally within \pm 5 ( Narany et al., 2014). However, if the laboratory did not test for one of the essential cations or anions, then a correct balance cannot be calculated (Hoaghia et al., 2015; Dalai et al., 2002). The relative ion concentration is represented graphically in Fig. 3.

According to the ion balance diagram, all 45 water samples $\mathrm{Cl}^{-}$and $\mathrm{Na}-\mathrm{K}$ type. In post-monsoon season $\mathrm{SO}_{4}{ }^{2-}$ is the lowest concentration, and in the premonsoon season, both $\mathrm{SO}_{4}{ }^{2-}$ and $\mathrm{HCO}_{3}{ }^{-}$are the lowest ionic concentration. Piper diagram is a graphical representation of the chemistry of water samples (Fig. 4). It is suitable for comparing the ionic composition of a set of water samples. In the piper diagram, the cations and anions have shown by separate ternary plots. These plotted points in triangular fields are projected in the central diamond field, which helps determine the overall character of the water (Sajil Kumar, 2013). The total cations in $\mathrm{meq} / \mathrm{l}$ and the total anions in $\mathrm{meq} / \mathrm{l}$ are set equal to $100 \%$ of the water sample.

Datasets are displayed as a diamond grid in Fig. 4 to show the total ion relationships-three data points in each triangle representing the individual sample (Babu et al., 2015). The assessment of geochemical properties was estimated by concentration (meq/l) levels of anions $\left(\mathrm{HCO}_{3}{ }^{-}, \mathrm{SO}_{4}{ }^{2-}\right.$ and $\left.\mathrm{Cl}^{-}\right)$and cations

$\left(\mathrm{Ca}^{2+}, \mathrm{Mg}^{2+}, \mathrm{Na}^{+}\right.$, and $\left.\mathrm{K}^{+}\right)$in collected groundwater samples. Several researchers have conducted similar types (Yang et al., 2016; Mapoma et al., 2016; Krishna et al., 2015; Suma et al., 2015). In Fig. 6, 60\%, 15\%, 15\%, and 10\% of samples representing the quality of water like mixed types $\mathrm{Na}-\mathrm{Mg}$-Ca-Cl-HCO 3 , Na-Mg-Ca$\mathrm{Cl}$ type, $\mathrm{Na}-\mathrm{Mg}-\mathrm{Cl}-\mathrm{HCO}_{3}$ and $\mathrm{Na}-\mathrm{Mg}-\mathrm{Cl}$, respectively, whereas in anion triangle are showing chloride type, dominant type and bicarbonate type with $70 \%, 20 \%$ and $10 \%$, respectively, which indicated that water is approximately $70 \%$ salted in nature.

To determine water-based major cations - anions in collected samples Durov diagram are presented in Fig. 5 (Gomo and Vermeulen, 2014), where two separate triangle plots are presenting the cations and anions values (Azaza et al., 2011; Nagaraju et al., 2016). According to previous studies (Azaza et al., 2011; Fiky, 2010; Chang and Wang, 2010), data plotted in the base of the triangle and lies perpendicular to the third axis in each triangle are provided information about vertex elements concentration which lost in the square gird. In Durov diagram (Fig. 5), the TDS and pH values are graphically represented by cationic and anionic concentration.

The result shows that in the post-monsoon season, TM 240 and TM 259 water samples have a higher value for TDS and in the pre-monsoon season, water samples of TM 59 and TM 295 have a higher concentration on TDS. Since TDS concentration in groundwater exceeds 1000 mg/l in both post-monsoon and pre-monsoon indicates that the groundwater is generally saline or brackish. Brackish water has a TDS concentration in the range between 1000 to 10000 $\mathrm{mg} / \mathrm{l}$. The determination of variability of water irrigation purpose has been done by Wilcox plot, where It classifies according to sodium hazard (SAR) and salinity hazard (conductivity) (Srinivasamoorthy et al., 2014). The interpretation, through EC vs. SAR values, of water quality suitable for the irrigation purpose.SAR has been estimated from the incremental ionic concentration of $\mathrm{Na}^{+}, \mathrm{Ca}^{2+}$, andMg $\mathrm{Mg}^{2+}$ according to the following relationship(Velasco et al., 2014).

$\mathrm{SAR}=N a / \sqrt{ }\left(\frac{C a+M g}{2}\right)$

Where the quantities of $\mathrm{Ca}^{2+}, \mathrm{Mg}^{2+}$, and $\mathrm{Na}^{+}$are expressed in milliequivalents per liter.

The concentration levels of minerals determine the suitability of water for irrigation to show its effects on soil and plants (Rammohan and Jeevanandam 2009). Earlier studies indicated a higher concentration of sodium in the soil, displace the available $\mathrm{Mg}^{2+}$, and $\mathrm{Ca}^{2+}$ ions. In this regard, soil having low permeability and showing poor internal drainage (Helsel and Hirsch, 2002; Sadashivaiah et al., 2015). Figure 6 shows that water suitability for irrigation purposes has been presented, where values indicated that 70\% of collected samples fall in permissible limits (Selvakumar et al., 2017; Das et al., 2015; Hua et al., 2015).

Loading [MathJax]/jax/output/CommonHTML/jax.js 
The relationship between sodium adsorption and electrical conductivity is demonstrated using the US salinity diagram (Wilcox diagram). The analytical data outcomes indicated that $70 \%$ of samples are falling on the C3S1 type category and indicating high salinity and low sodium content. The results highlighted that it could be useful for irrigation in all soil types to provide a low risk of exchangeable sodium. On the other side, 20\% of samples are identified in C2S1, which indicates samples containing low alkalinity content and medium salinity. Such types of samples are very much suitable for plants having good salt tolerance.

In Fig. 7, a scatter plot indicating the influence of one variable on other variables (Umar et al., 2009). The scatter plot constructed for all sample data measured during 2016 and 2017 is presented (Figs. 7 \& 8). Here two quality variables are sampled at the same time. In post-monsoon season Fig. 6 , the 93030 samples have a higher correlation between $\mathrm{Ca}^{2+}$ and $\mathrm{Mg}^{2+}$. As a result, the $\mathrm{Ca}^{2+}$ increase concerning magnesium indicates that the hardness of the water samples is more. In Figs. 6 and 7, 93105 samples correlated with potassium and sodium. The sodium-rich groundwater occurs rock salt-bearing strata.

In Fig. 8, it can be seen that a good correlation has been found between $\mathrm{Cl}^{-}$and $\mathrm{Na}^{+}$through 93030 samples. As a result, the $\mathrm{Cl}^{-}$increases concerning Na+ indicates that high salinity in a water sample.

In the cross plot, dissolved solids and calcium correlated during study periods. In post-monsoon, Fig. 9 station TM-49 (Jan 2016) and TM-259 (Jan 2017) positively correlated between calcium and dissolved solids. In pre-monsoon, station TM-54 (Jul 2016) and TM-57 (Jul 2017 ) positively correlated between calcium and dissolved solids. The ratio of the concentration of major ions of individual samples has been plotted by using Pie charts. All parameters have been customizable using different colors and patterns (Qingchun Yang et al., 2016). The pie diagram (Fig. 10) shows that chloride and magnesium are the dominant anions and cation, respectively.

The total chloride $(\mathrm{mg} / \mathrm{l})$ has been reported $34.2 \%$ and $41.6 \%$ in post- and pre-monsoon time. According to higher concentration, the order of major cations in collected samples are $\mathrm{Na}^{+}>\mathrm{Ca}^{2+}>\mathrm{Mg}^{2+}>\mathrm{K}^{+}$, while $\mathrm{Cl}^{-}>\mathrm{HCO}_{3}{ }^{-}>\mathrm{SO}_{4}{ }^{2-}$ has been reported for anions in study area. Semi - logarithmic diagrams indicate major ion analysis (meq/l) with different hydro-chemical water types (Uzoije et al., 2014). The actual sample concentrations are displayed and compared are the main advantage of this graphical representation, like trilinear diagrams (Narany et al., 2014). In Fig. 11, the Schoeller diagram is presenting a plot of all samples in the open database. A total of 12 different parameters are demonstrated along with the $x$-axis. The symbols represent the sample points in a customized manner into shape and color. All the highlighted lines are indicated specific samples selected in the database (Zaidi et al., 2016; Fianko et al., 2010). Cations $\left(\mathrm{Na}^{+}, \mathrm{K}^{+}\right.$, and $\left.\mathrm{Mg}^{2+}\right)$ and anions $\left(\mathrm{Cl}^{-}, \mathrm{SO}_{4}^{2-}\right.$, and $\left.\mathrm{HCO3}^{-}\right)$have been plotted on the right and left sides, respectively. The higher concentration of $\mathrm{Cl}^{-}$ion indicated the salt content in the selected study area.

In Fig. 12, radial diagrams have been plotted for a single sample as the graphically comparing the measured parameter concentration for several individual samples. Kumar et al. (2006) reported that radial diagrams are handy for identifying different water facies' geographic locations with the same composition. An average of 12 chemical parameters has been presented using two clusters in the stiff diagram. In this regard, $\mathrm{Na}^{+}$and $\mathrm{Cl}^{-}$are observed as dominant cation and anion, respectively (Uzoije et al., 2014).

\section{Conclusion}

A comprehensive assessment has been done to develop groundwater quality fluctuation factors in selected study sites "semi-arid region of Thamirabarani river" during monsoon (Pre \& Post) season by analyzing and interpreting 45 samples. The physicochemical result determines the groundwater is generally alkaline. The higher concentration of selected ions has been observed in the following order; $\mathrm{Ca}^{2+}>\mathrm{Mg}^{2+}>\mathrm{Na}^{+}\left\langle\mathrm{Cl}^{-}>\mathrm{HCO}_{3}{ }^{-}>\mathrm{SO}_{4}{ }^{2-}>\mathrm{NO}_{3}{ }^{-}\right.$. On the other hand, $\mathrm{Ca}-$ $\mathrm{Mg}-\mathrm{HCO}_{3}{ }^{-}, \mathrm{Mg}-\mathrm{Ca}-\mathrm{Cl}, \mathrm{Na}-\mathrm{C1}$, and infused waters have been identified in the basin area, which is not representing anion and cation dominates. Due to increased concentration chloride in a water sample indicates that it is unsuitable or causes major problems for drinking purpose, this is mainly caused due to the inappropriate discharge of domestic sewage, excessive application of agricultural fertilizers and also due to the abundant growth of population which may lead to groundwater deterioration in the surrounding environment.

\section{Declarations}

\section{Conflict of Interest}

There is no conflict of interest.

\section{Acknowledgments}

SG is thankful to Karunya University, Coimbatore, Tamil Nadu, India, for providing us the required funding and support during fieldwork and analysis.

\section{References}

A. O Talabi, O. L. Afolagboye, M. N. Tijani, J. A. Aladejana, A. K. Ogundana, 2013. Hydrogeochemical Assessment of Surface Water in the Central Part of EkitiState, Southwestern Nigeria. Am. J. Water Resour. 1, 56-65. https://doi.org/10.12691/ajwr-1-4-1

A. W. Jayawardena, 2010. Environmental and Hydrological Systems Modelling.

A.P Uzoije, A. Onunkwo-A, Uche C.C, D Ashiegbu, 2014. Evaluation of Groundwater Quality of Coastal Aquifer Systems in Buguma City , Rivers State South- 
Abdulrafiu O. Majolagbe, Adeleke A. Kasali, Lateef .O Ghaniyu, 2011. Quality assessment of groundwater in the vicinity of dumpsites in Ifo and Lagos , Southwestern Nigeria. Adv. Appl. Sci. Res. 2, 289-298.

Alaa A. Masoud, Katsuaki Koike, Hamdy A. Mashaly, Fibi Gergis, 2016. Spatio-temporal trends and change factors of groundwater quality in\&nbsp;an arid area with peat rich aquifers: Emergence of water environmental problems in Tanta District, Egypt. J. Arid Environ. J. 17.

https://doi.org/doi:10.1016/j.jaridenv.2015.08.018

Anpalaki J. Ragavan, George C. Fernandez, 2010. Modeling Water Quality Trend in Long Term Time Series, in: Statistics and Data Analysis. p. 10.

Anwar A. El-Fiky, 2010. Hydrogeochemical characteristics and evolution of groundwater at the Ras Sudr-Abu Zenima area, southwest Sinai, Egypt. J. King Abdulaziz Univ. Earth Sci. 21, 79-109. https://doi.org/10.4197/Ear.21-1.4

Anwar Zahid, M. Qumrul Hassan, K.-D. Balke, Matthias Flegr, David W. Clark, 2008. Groundwater chemistry and occurrence of arsenic in the Meghna floodplain aquifer, southeastern Bangladesh. Environ. Geol. 54, 1247-1260. https://doi.org/10.1007/s00254-007-0907-3

APHA, 1999. Standard Methods for the Examination of Water and Wastewater, in: American Public Health Association. p. 541.

Arveti Nagaraju, P. Muralidhar, Y. Sreedhar, 2016. Hydrogeochemistry and Groundwater Quality Assessment of Rapur Area , Andhra. J. Geosci. Environ. Prot. 4, $88-99$.

Ate Visser, Igor Dubus, Hans Peter Broers, Serge Brouyere, 2009. Comparison of methods for the detection and extrapolation of trends in groundwater quality. J. Environ. Monit. 11, 20-30. https://doi.org/10.1039/b905926a

Atiqur Rahman, 2008. A GIS based DRASTIC model for assessing groundwater vulnerability in shallow aquifer in Aligarh , India. Appl. Geogr. $28,32-53$. https://doi.org/10.1016/j.apgeog.2007.07.008

Avijit Das, Dilip Kumar Bandopadhyay, Pravas Kumar Jee, Indrarup Roy Chowdhury, 2015. Hydrogeochemistry of groundwater in Chandanpur area of Odisha, India. Int. J. GEOMATICS Geosci. 5, 448-458.

Bin Hua, John Yang, Baolin Deng, 2015. Groundwater Quality, in: Practical and Applied Hydrogeology. pp. 279-339. https://doi.org/10.1016/B978-0-12800075-5.00005-4

Biswajeet Pradhan, Saied Pirasteh, 2011. Hydro-Chemical Analysis of the Ground Water of the Basaltic Catchments: Upper Bhatsai Region , Maharastra. open Hydrol. J. 5, 51-57.

Bureau of Indian Standards for drinking water - specification - IS-10500, 2012. , New Delhi.

C. Gajendran, P. Thamarai, 2008. Study on statistical relationship between groundwater quality parameters in Nambiyar river basin, Tamilnadu, India. Pollut. Res. 27, 679-683.

Changlai Xiao, Jinfeng Liu, Xiujuan Liang, Shanghai Du, 2016. Hydrogeochemistry characteristics of groundwater and its suitability for water supply and irrigation in Jilin City, China. Arab. J. Geosci. 9, 1-11. https://doi.org/10.1007/s12517-016-2447-1

Chen-Wuing Liu, Kao-Hung Lin, Yi-Ming Kuo, 2003. Application of factor analysis in the assessment of groundwater quality in a blackfoot disease area in Taiwan. Sci. Total Environ. 313, 77-89. https://doi.org/10.1016/S0048-9697(02)00683-6

D.R. Helsel, R.M. Hirsch, 2002a. Statistical Methods in Water Resources, U.S. Geological survey.

D.R. Helsel, R.M. Hirsch, 2002b. Statistical Methods in Water Resources, Hydrologic Analysis and Interpretation. https://doi.org/10.2307/1269385

D S. Rajendra Prasad, C. Sadashivaiah, G. Rangnna, 2009. Hydro-chemical Characteristics and Evaluation of Groundwater Quality of Tumkur Amanikere Lake Watershed, Karnataka, India. J. Chem. 6, 211-219.

David N. Lerner, Bob Harris, 2009. The relationship between land use and groundwater resources and quality. Land use policy 26, $265-273$.

https://doi.org/10.1016/j.landusepol.2009.09.005

Dr.C. Gajendran, S. Jayapriya, Diana Yohannan, Oshin Victor, Christina Jacob, 2013. Assessment of groundwater quality in Tirunelveli District, Tamil Nadu , India. Int. J. Environ. Sci. 3, 1874-1880. https://doi.org/10.6088/ijes.2013030600009

Durdu Omer Faruk, 2010. A hybrid neural network and ARIMA model for water quality time series prediction. Eng. Appl. Artif. Intell. J. 23, 586-594. https://doi.org/10.1016/j.engappai.2009.09.015

Dutta, S., 2017. swachhindia [WWW Document]. URL http://swachhindia.ndtv.com/76-million-dont-have-safe-drinking-water-indias-looming-water-crisis-5606/ (accessed 12.4.17).

Elke Bozau, Carl-Diedrich Sattler, Wolfgang van Berk, 2015. Hydrogeochemical classification of deep formation waters. Appl. Geochemistry 52, $23-30$. https://doi.org/10.1016/j.apgeochem.2014.10.018

Loading [MathJax]/jax/output/CommonHTML/jax.js 
Fadoua Hamzaoui-Azaza, Mouna Ketata, Rachida Bouhlila, Moncef Gueddari, Luis Riberio, 2011. Hydrogeochemical characteristics and assessment of drinking water quality in Zeuss - Koutine aquifer, southeastern Tunisia. Environ. Monit. Assess. 174, 283-298. https://doi.org/10.1007/s10661-010-1457-9

Faisal K. Zaidi, Saad Mogren, Manoj Mukhopadhyay, Elkhedr Ibrahim, 2016. Evaluation of groundwater chemistry and its impact on drinking and irrigation water quality in the eastern part of the Central Arabian graben and trough system, Saudi Arabia. J. African Earth Sci. 120, 208-219.

https://doi.org/10.1016/j.jafrearsci.2016.05.012

Government of Tamilnadu Water Resources Organisation public work department, 2015.

Graham B Mcbride, 2005. Using Statistical Methods for Water Quality Management. Natl. Inst. Water Atmos. Res. 22.

Guidelines for Drinking-water Quality, 2008. , Geneva.

H Kim, Chung, S.Y., 2011. Application of Multivariate statistical analysis for the evaluation of groundwater contamination characteristics at the Suyeong-gu of Busan city. Korea. J. Geol. Soc. Korea 47, 45-58.

Hamzaoui-Azaza, F., Ketata, M., Bouhlila, R., Gueddari, M., Riberio, L., 2011. Hydrogeochemical characteristics and assessment of drinking water quality in Zeuss-Koutine aquifer, southeastern Tunisia. Environ. Monit. Assess. 174, 283-298. https://doi.org/10.1007/s10661-010-1457-9

Harold Hotelling, 1933. Analysis of a complex of statistical variables into Principal Components. J. Educ. Psychol. 24, 417-441.

Harold Wilson Tumwitike Mapoma, Xianjun Xie, Liping Zhang, Mathews Tananga Nyirenda, Albert Maliro, Darlington Chimutu, 2016. Hydro-chemical characteristics of rural community groundwater supply in Blantyre, southern Malawi. J. African Earth Sci. 114, 192-202.

https://doi.org/10.1016/j.jafrearsci.2015.11.023

Hongbing Sun, Manfred Koch, 1996. Time Series Analysis of Water Quality Parameters in an Estuary using Box-Jenkins ARIMA Models and Cross-Correlation Techniques.

Ifeanyi Francis Offor, Ifeanyi Francis Offor, Ikechukwu Moses Onwe, 2015. Hydrogeochemical attributes and ground water quality of Ngbo Community in Ohaukwu Area Council , Ebonyi State, Nigeria. An Interdiscip. J. Appl. Sci. 10. https://doi.org/10.4136/1980-993X

Intissar Farid, Rim Trabelsi, Kamel Zouari, Kamel Abid, Mohamed Ayachi, 2013. Hydrogeochemical processes affecting groundwater in an irrigated land in Central Tunisia. Environ. Earth Sci. 68, 1215-1231. https://doi.org/10.1007/s12665-012-1788-7

Joseph Richmond Fianko, Dickson Adomako, Shiloh Osae, Samuel Ganyaglo, Benony K. Kortatsi, Collins K. Tay, Eric T. Glover, 2010. The hydrochemistry of groundwater in the Densu River Basin, Ghana. Environ. Monit. Assess. 167, 663-674. https://doi.org/10.1007/s10661-009-1082-7

Juan Chang, Genxu Wang, 2010. Major ions chemistry of groundwater in the arid region of Zhangye Basin , northwestern China. Environ. Earth Sci. 61, 539547. https://doi.org/10.1007/s12665-009-0364-2

K. Srinivasamoorthy, M. Gopinath, S. Chidambaram, M. Vasanthavigar, V.S. Sarma, 2014. Hydro-chemical characterization and quality appraisal of groundwater from Pungar sub basin, Tamilnadu, India. J. King Saud Univ. - Sci. 26, 37-52. https://doi.org/10.1016/j.jksus.2013.08.001

K. Srinivasamoorthy, M. Vasanthavigar, K. Vijayaraghavan, R. Sarathidasan, S. Gopinath, 2011. Hydrochemistry of groundwater in a coastal region of Cuddalore district, Tamilnadu , India: implication for quality assessment. Arab. J. Geosci. https://doi.org/10.1007/s12517-011-0351-2

Kisi, O., Ay, M., 2014. Comparison of Mann-Kendall and innovative trend method for water quality parameters of the Kizilirmak River, Turkey. J. Hydrol. 513, 362-375. https://doi.org/10.1016/j.jhydrol.2014.03.005

Krishna, S., Logeshkumaran, A., Magesh, N.S., Godson, P.S., Chandrasekar, N., 2015. Hydro-geochemistry and application of water quality index ( WQI ) for groundwater quality assessment, Anna Nagar, part of Chennai City , Tamil Nadu , India. Appl. Water Sci. 335-343. https://doi.org/10.1007/s13201-014-01964

Lazhar Belkhiri, Abderrahmane Boudoukha, Lotfi Mouni, Toufik Baouz, 2010. Application of multivariate statistical methods and inverse geochemical modeling for characterization of groundwater - A case study: Ain Azel plain (Algeria). Geoderma 159, 390-398.

https://doi.org/10.1016/j.geoderma.2010.08.016

Leif Wolf, Inka Held, Matthias Eiswirth, Heinz Hötzl, 2004. Impact of leaky sewers on groundwater quality. Acta Hydrochim. Hydrobiol. $32,361-373$. https://doi.org/10.1002/aheh.200400538

M. A. M Joarder, F. Raihan, J. B. Alam, S. Hasanuzzaman, 2008. Regression Analysis of Ground Water Quality Data of Sunamganj District, Bangladesh. Int. J. Environ. Res. Public Health 2, 291-296.

M. Gomo, D. Vermeulen, 2014. Hydrogeochemical characteristics of a flooded underground coal mine groundwater system. J. African Earth Sci. $92,68-75$. https://doi.org/10.1016/j.jafrearsci.2014.01.014

Loading [MathJax]/jax/output/CommonHTML/jax.js 
M. Vasanthavigar, K. Srinivasamoorthy, K. Vijayaragavan, R. Rajiv Ganthi, S. Chidambaram, P. Anandhan, S. Vasudevan, Manivannan, R., 2010. Application of water quality index for groundwater quality assessment: Thirumanimuttar sub-basin, Tamilnadu, India. Environ. Monit. Assess. 171, 595-609.

https://doi.org/10.1007/s10661-009-1302-1

Magesh, N.S., Chandrasekar, N., 2014. GIS model-based morphometric evaluation of Tamiraparani subbasin, Tirunelveli district, Tamil Nadu, India. Arab. J. Geosci. 7, 131-141. https://doi.org/10.1007/s12517-012-0742-z

Mahesh Kumar.Akkaraboyina, prof B.S.N.Raju, 2012. It observed IOSR J. Mech. Civ. Eng. 1, 39-44. https://doi.org/10.9790/1684-0133944

Manish Kumar, AL. Ramanathan, M. S. Rao, Bhishm Kumar, 2006. Identification and evaluation of hydrogeochemical processes in the groundwater environment of Delhi, India. Environ. Geol. 50, 1025-1039. https://doi.org/10.1007/s00254-006-0275-4

Manoj K, Ghosh S, Padhy P.K, 2013. Characterization and Classification of Hydrochemistry using Multivariate Graphical and Hydrostatistical Techniques. Res. J. Chem. Sci. 3, 32-42.

Maria-Alexandra Hoaghia, Cecilia Roman, Claudiu Tănăselia, Dumitru Ristoiu, 2015. Groundwater chemistry rendering using Durov, Piper and lon Balance diagram. Study case: The Northern part of Sibiu Country. Environ. Earth Sci. 2, 161-168.

Mir Mehrdad Mirsanjari, Fatemeh Mohammadyari, 2018. Application of Time-series Model to Predict Groundwater Quality Parameters for Agriculture: ( Plain Mehran Case Study ). IOP Conf. Ser. Earth Environ. Sci. 127, 012012.

Mohesn Saeedi, Ozeair Abessi, Farid Sharif, Hamed Meraji, 2010. Development of groundwater quality index. Environ. Monit. Assess. 163, $327-335$. https://doi.org/10.1007/s10661-009-0837-5

Monitoring of Indian National Aquatic Resources (MINARS) and Global Environmental Monitoring System (GEMS) [WWW Document], n.d. . Tamilnadu Pollut. Control board. URL http://www.tnpcb.gov.in/water-quality.php (accessed 12.4.17).

N.K Babithesh Babu, C. Gajendran, A. Shahul Hameed, E.J James, 2015. Appraisal of Groundwater Quality for Drinking and Irrigation Purposes in Nambiyar River Basin , Tamil Nadu , India. Water Resour. Dev. 42, 553-562. https://doi.org/10.1134/S009780781504003X

Nikolaos Voutsis, Efstratios Kelepertzis, Evangelos Tziritis, Akindynos Kelepertsis, 2015. Assessing the hydrogeochemistry of groundwaters in ophiolite areas of Euboea Island, Greece, using multivariate statistical methods. J. Geochemical Explore. 159, 79-92. https://doi.org/10.1016/j.gexplo.2015.08.007

P. Thillai Arasu, S. Hema, M.A. Neelakantan, 2007. Physico-chemical analysis of Tamirabarani river water in South India. Indian J. Sci. Technol. 1, 1-6.

P.J Sajil Kumar, 2013. Interpretation of groundwater chemistry using piper and chadha's diagrams: a comparative study from perambalur. Geoscience 54, $12208-12211$.

Paul A. Conrads, Edwin A. Roehl, Jr., R.C.D., Francis H. Chapelle, Mark A. Lowery, Uwe H. Mundry, 2007. Visualization and Time-Series Analysis of GroundWater Data for C-Area, Savannah River Site, South Carolina, 1984-2004.

Piper, A.M., 1953. A graphic procedure in the geochemical interpretation of water analysis. U.S. Department of the Interior, Geological Survey, Water Resources Division, Ground Water Branch.

Qingchun Yang, Zijun Li, Hongyun Ma, Luchen Wang, Jordi Delgado Martín, 2016. Identi fi cation of the hydrogeochemical processes and assessment of groundwater quality using classic integrated geochemical methods in the Southeastern part of Ordos basin , China. Environ. Pollut. 1-10.

https://doi.org/10.1016/j.envpol.2016.08.017

Rashid Umar, Izrar Ahmed, Fakhre Alam, Mohammad Muqtada Khan, 2009. Hydro-chemical characteristics and seasonal variations in groundwater quality of an alluvial aquifer in parts of Central Ganga Plain, Western Uttar Pradesh, India. Environ. Geol. 58, 8. https://doi.org/10.1007/s00254-008-1630-4

Rosemary K. Le, Christopher V. Rackauckas, Anne S. Ross, Nehemias Ulloa, n.d. Assessment of Statistical Methods for Water Quality Monitoring in Maryland ' s Tidal Waterways.

S. Krishna Kumar, V. Rammohan, J. Dajkumar Sahayam, M. Jeevanandam, 2009. Assessment of groundwater quality and hydrogeochemistry of Manimuktha River basin , Tamil Nadu , India. Environ. Monit. Assess. 159, 341-351. https://doi.org/10.1007/s10661-008-0633-7

S. Y. Chung, S. Venkatramanan, T. H. Kim, D. S. Kim, T. Ramkumar, 2015. Influence of hydrogeochemical processes and assessment of suitability for groundwater uses in Busan City, Korea. Environ. Dev. Sustain. 17, 423-441. https://doi.org/10.1007/s10668-014-9552-7

S.Anandakumar, T.Subramani, Ramasamy Nagarajan, L.Elango, 2009. Subsurface Hydrogeochemical Processes in Lower Bhavani River Basin , Tamil Nadu , India, in: 1st International Symposium on Geology, Curtin University. pp. 7-10. https://doi.org/ISG-09-P03

Sadashivaiah, C., Ramakrishnaiah, C.R., Ranganna, G., 2015. Hydro-chemical Analysis and Evaluation of Groundwater Quality in Tumkur Taluk, Karnataka. Int. J. Environ. Res. Public Health. https://doi.org/10.3390/ijerph5030158

Loading [MathJax]/jax/output/CommonHTML/jax.js 
Sajitha V, Smitha Asok Vijayamma, 2016. Study of Physico-Chemical Parameters and Pond Water Quality Assessment by using Water Quality Index at Athiyannoor Panchayath, Kerala , India. Emergent life Sci. Res. 2, 46-51.

Salim Aijaz Bhat, Gowhar Meraj, Sayar Yaseen, Ashok K. Pandit, 2014. Statistical Assessment of Water Quality Parameters for Pollution Source Identification in Sukhnag Stream: An Inflow Stream of Lake Wular ( Ramsar Site ), Kashmir Himalaya. J. Ecosyst. 18.

Samuel Y. Ganyaglo, Shiloh Osae, Samuel B. Dampare, Joseph R. Fianko, Mohammad A. H. Bhuiyan, Abass Gibrilla, Edward Bam, Elikem Ahialey, Juliet Osei, 2012. Preliminary groundwater quality assessment in the central region of Ghana. Environ. Earth Sci. 66, 573-587. https://doi.org/10.1007/s12665-011-12667

Shekhar, S., Kumar, S., Densmore, A.L., van Dijk, W.M., Sinha, R., Kumar, M., Joshi, S.K., Rai, S.P. and Kumar, D., 2020. Modelling water levels of northwestern India in response to improved irrigation use efficiency. Scientific reports, 10(1), pp.1-15.

Simge Varol, Aysen Davraz, 2014. Assessment of geochemistry and hydrogeochemical processes in groundwater of the Tefenni plain (Burdur/Turkey). Environ. Earth Sci. 71, 4657-4673. https://doi.org/10.1007/s12665-013-2856-3

Sinha, R., Joshi, S.K. and Kumar, S., 2019. Aftershocks of the green revolution in Northwest India. Geography and You, 19(24), pp.12-19.

Sujatha, 2017. World Water Day 2017: Water Scarcity in India | My India [WWW Document]. URL https://www.mapsofindia.com/my-india/india/world-waterday-2017-indias-wake-up-call (accessed 11.26.17).

Suma CS, Srinivasamoorthy K, Saravanan K, Faizalkhan A, Prakash R, Gopinath S, 2015. Geochemical Modeling of Groundwater in Chinnar River Basin: A Source Identification Perspective. Aquat. Procedia 4, 986-992. https://doi.org/10.1016/j.aqpro.2015.02.124

Susheel Kumar, 2013. Status of Water Quality in India-2012, in: Monitoring of Indian National Aquatic Resources. p. 247.

T. K. Dalai, S. Krishnaswami, M. M. Sarin, 2002. Major ion chemistry in the headwaters of the Yamuna river system: Chemical weathering, its temperature dependence and CO 2 consumption in the Himalaya. Geochim. Cosmochim. Acta 66, 3397-3416.

T. Subramani, N. Rajmohan, L. Elango, 2010a. Groundwater geochemistry and identification of hydrogeochemical processes in a hard rock region, Southern India. Environ. Monit. Assess. 162, 123-137. https://doi.org/10.1007/s10661-009-0781-4

Tahoora Sheikhy Narany, Mohammad Firuz Ramli, Ahmad Zaharin Aris, Wan Nor Azmin Sulaiman, Hafizan Juahir, Kazem Fakharian, 2014. Identification of the hydrogeochemical processes in groundwater using classic integrated geochemical methods and geostatistical techniques, in Amol-Babol Plain, Iran. Sci. World J. 15. https://doi.org/10.1155/2014/419058

V. Velasco, I. Tubau, Vázquez-Suñè, R. Gogu, D. Gaitanaru, M. Alcaraz, A. Serrano-Juan, 2014. GIS-based hydrogeochemical analysis tools (QUIMET). Comput. Geosci. 70, 164-180. https://doi.org/10.1016/j.cageo.2014.04.013

Waldron, S., n.d. "Mission Blue" Launched by National Geographic With Water Aid [WWW Document]. Environ. Clim. Chang. URL http://justmeans.com/blogs/mission-blue-launched-by-national-geographic-with-water-aid-india-and-bollywood (accessed 2.6.18).

Wayne R. Jones, Michael J. Spence, Adrian W. Bowman, Ludger Evers, Daniel A. Molinari, 2015. A software tool for the spatiotemporal analysis and reporting of groundwater monitoring data. Environ. Model. Softw. 55, 242-249. https://doi.org/10.1016/j.envsoft.2014.01.020

Wayne R. Jones, Michael J. Spence, Adrian W. Bowman, Ludger Evers, Daniel A. Molinari, 2013. Gwsdat - groundwater spatiotemporal data analysis tool.

Weihui Deng, Guoyin Wang, 2017. A novel water quality data analysis framework based on time-series data mining. J. Environ. Manage. 196, 365-375.

https://doi.org/10.1016/j.jenvman.2017.03.024

Weihui DGuoyin, Zhang, X., 2015. A novel hybrid water quality time series prediction method based on cloud model and fuzzy forecasting. Chemom. Intell. Lab. Syst. 149, 39-49. https://doi.org/10.1016/j.chemolab.2015.09.017

Yu Zhou, Yanxin Wang, Yilian Li, Francois Zwahlen, Julie Boillat, 2013. Hydrogeochemical characteristics of central Jianghan Plain, China. Environ. Earth Sci. 68, 765-778. https://doi.org/10.1007/s12665-012-1778-9

\section{Figures}



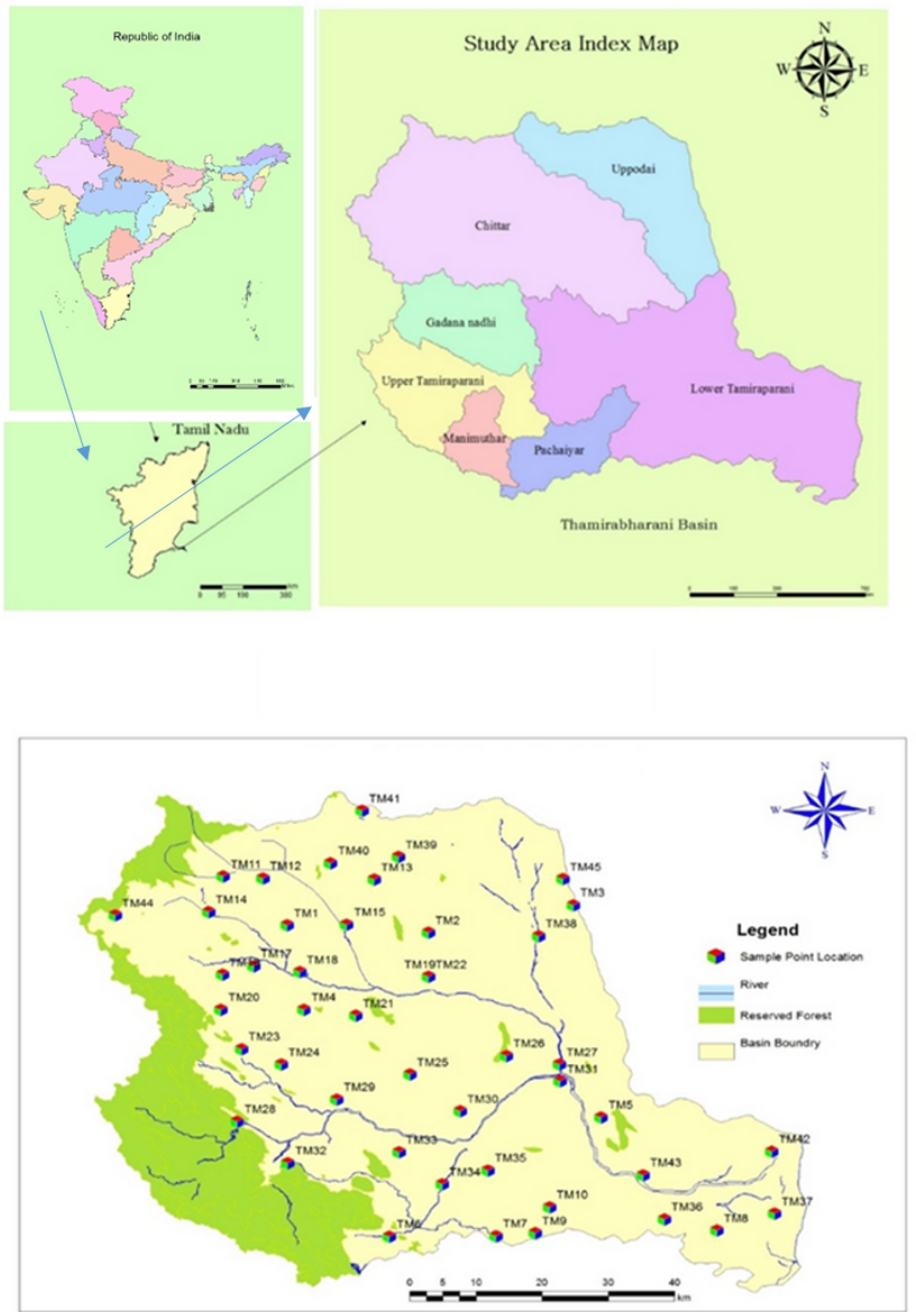

\section{Figure 1}

Thamirabarani river basin in Tamil Nadu, India. Note: The designations employed and the presentation of the material on this map do not imply the expression of any opinion whatsoever on the part of Research Square concerning the legal status of any country, territory, city or area or of its authorities, or concerning the delimitation of its frontiers or boundaries. This map has been provided by the authors. 

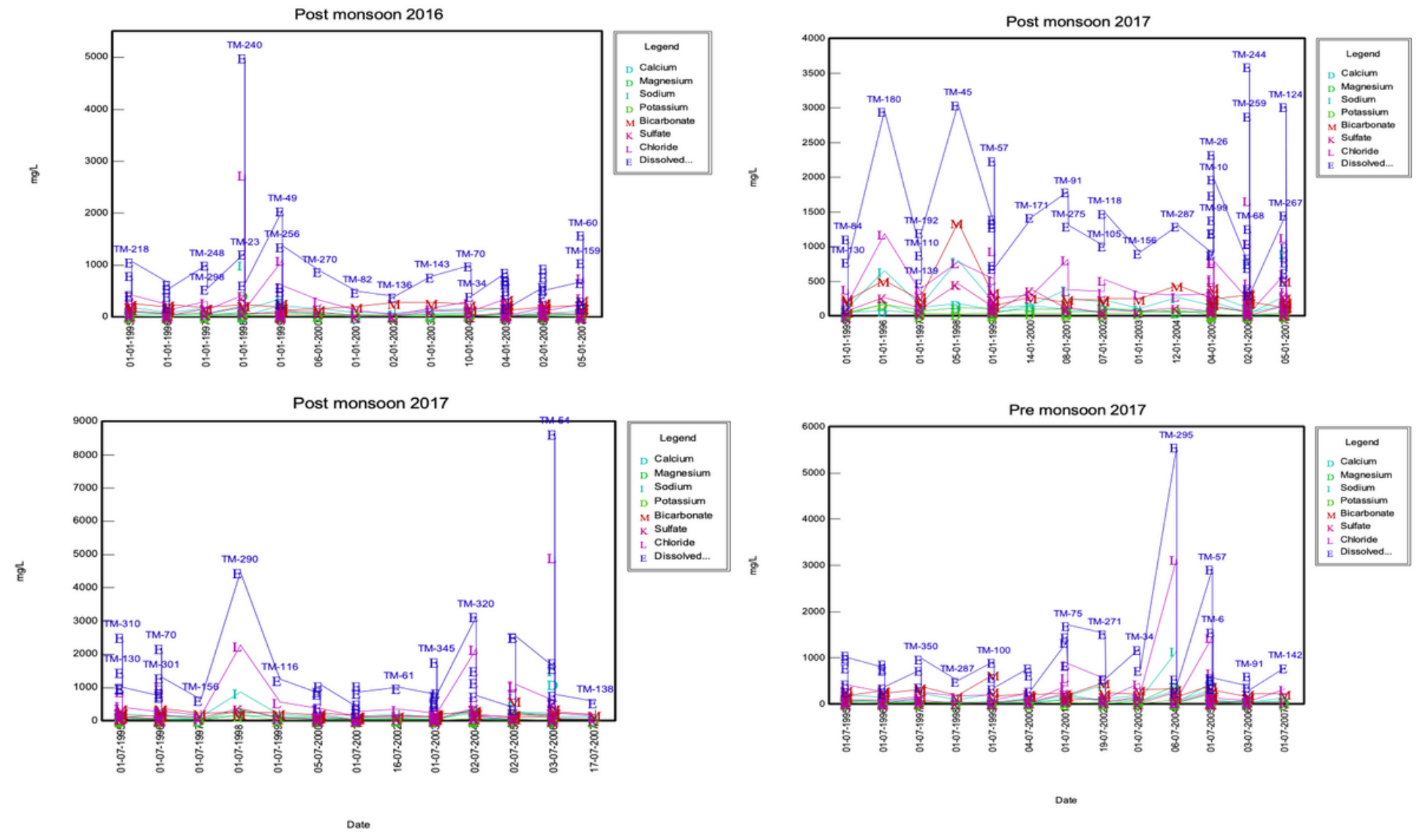

Figure 2

Time series analysis for post and pre-monsoon. 

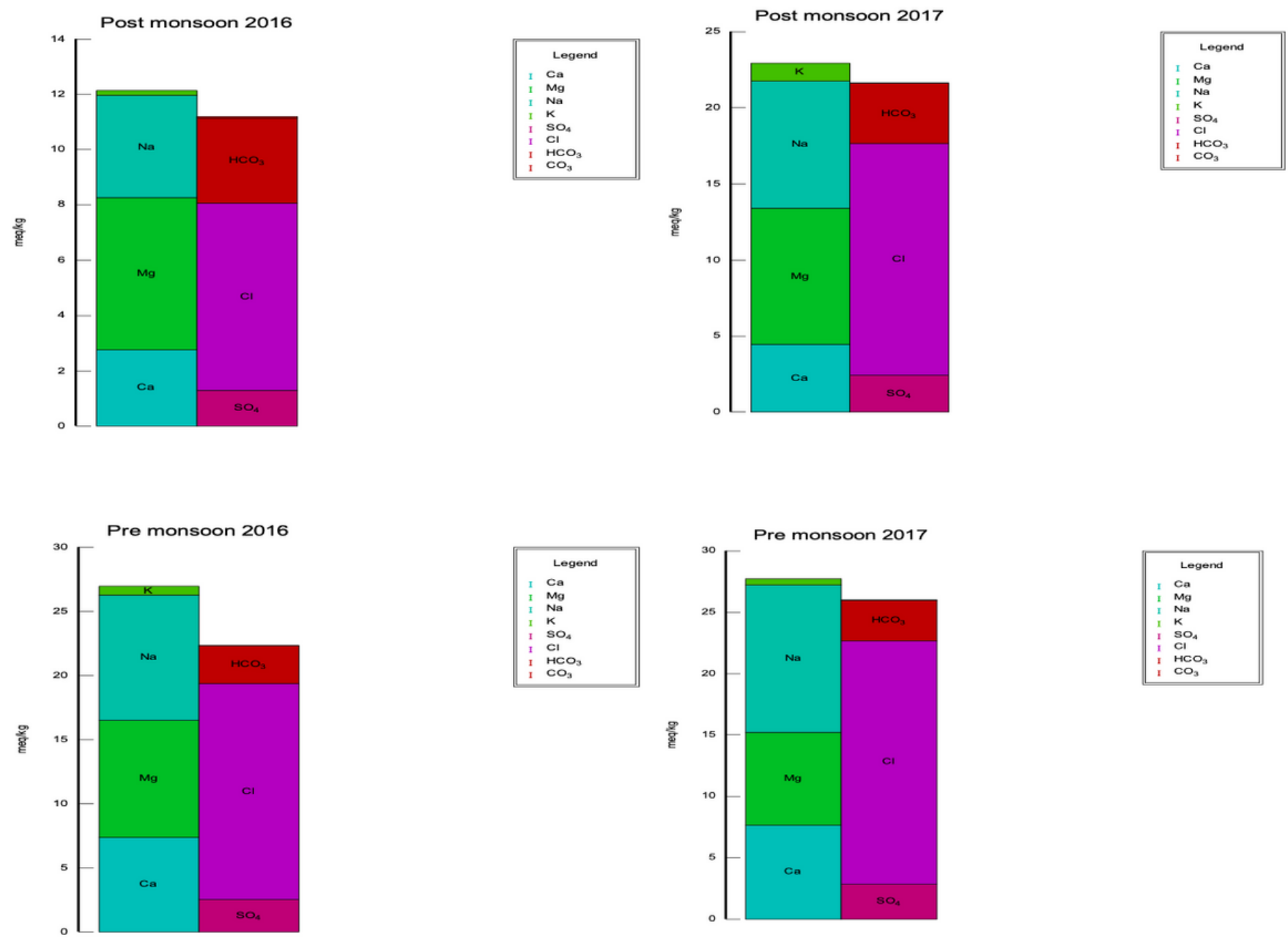

\section{Figure 3}

Ion balance diagram for post and pre-monsoon.
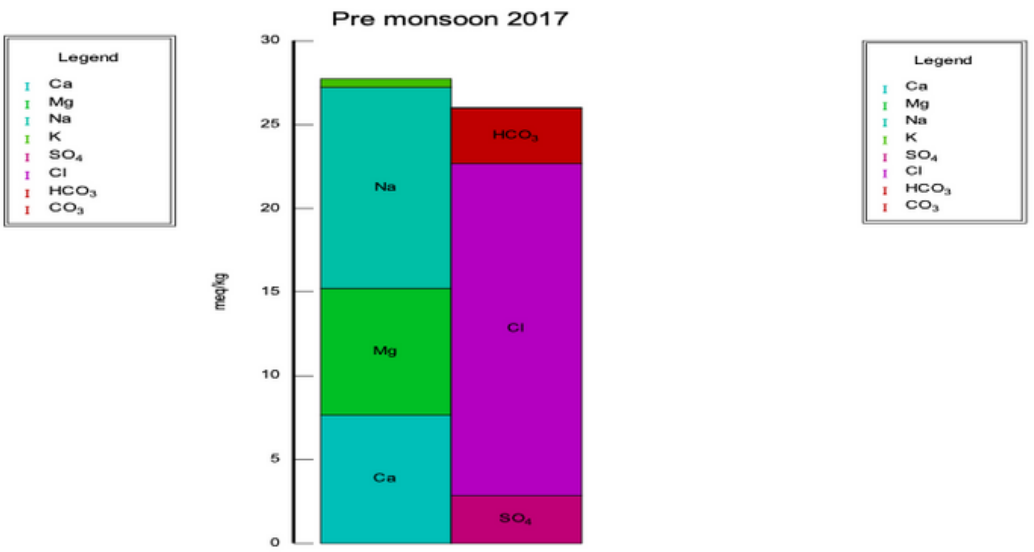


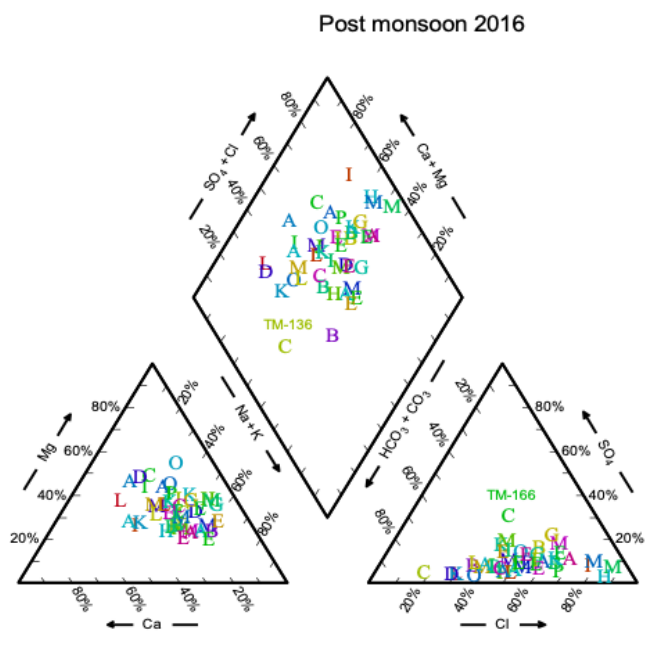

Pre monsoon 2016

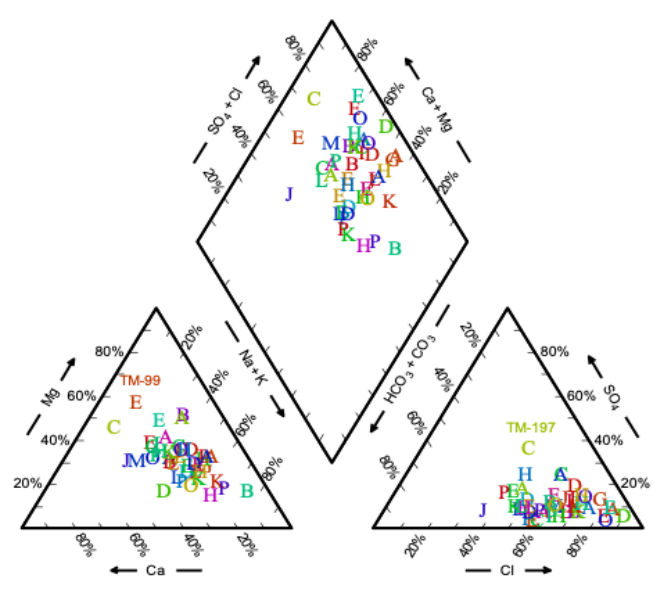

Figure 4

Piper trilinear diagram for post and pre-monsoon

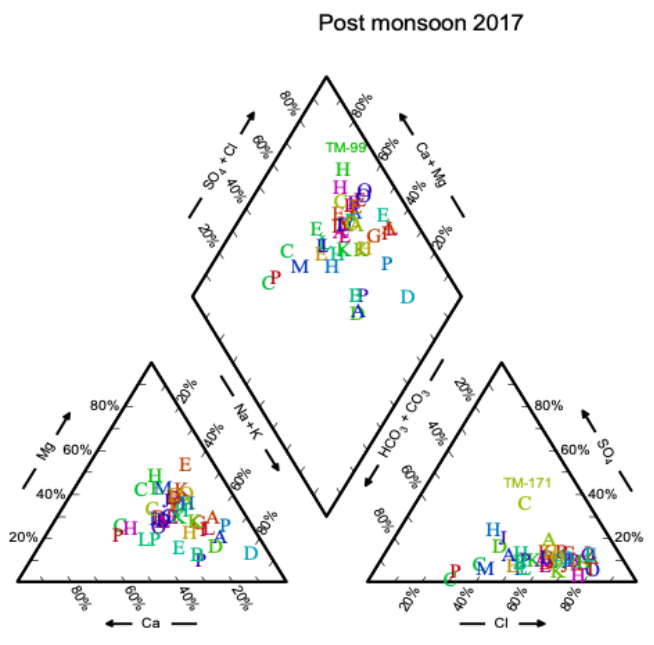

Pre monsoon 2017

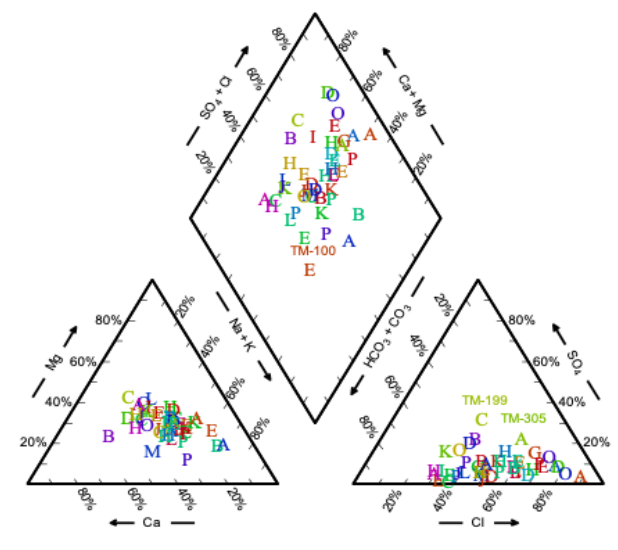



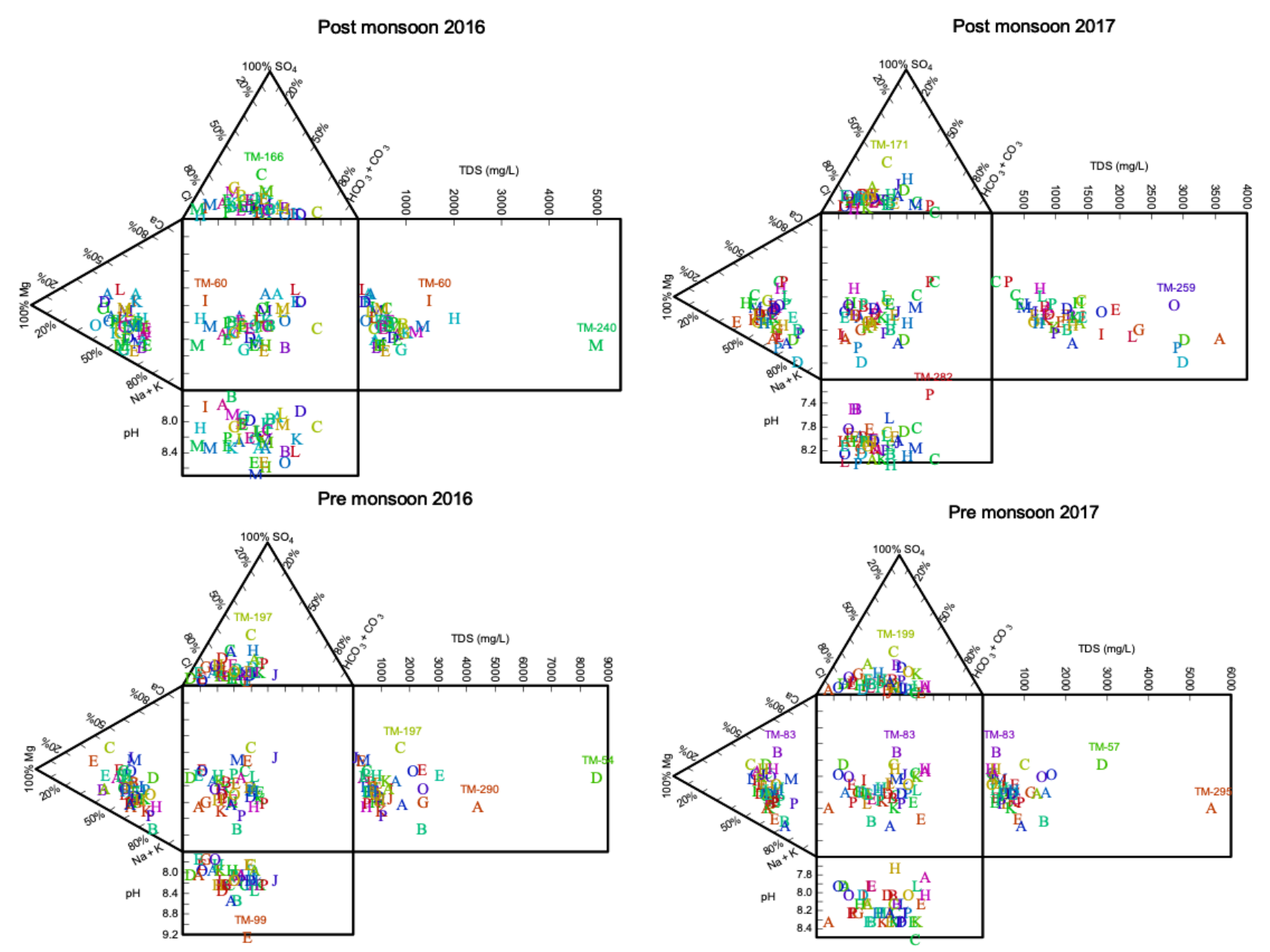

Figure 5

Durov plot for post- and pre-monsoon 

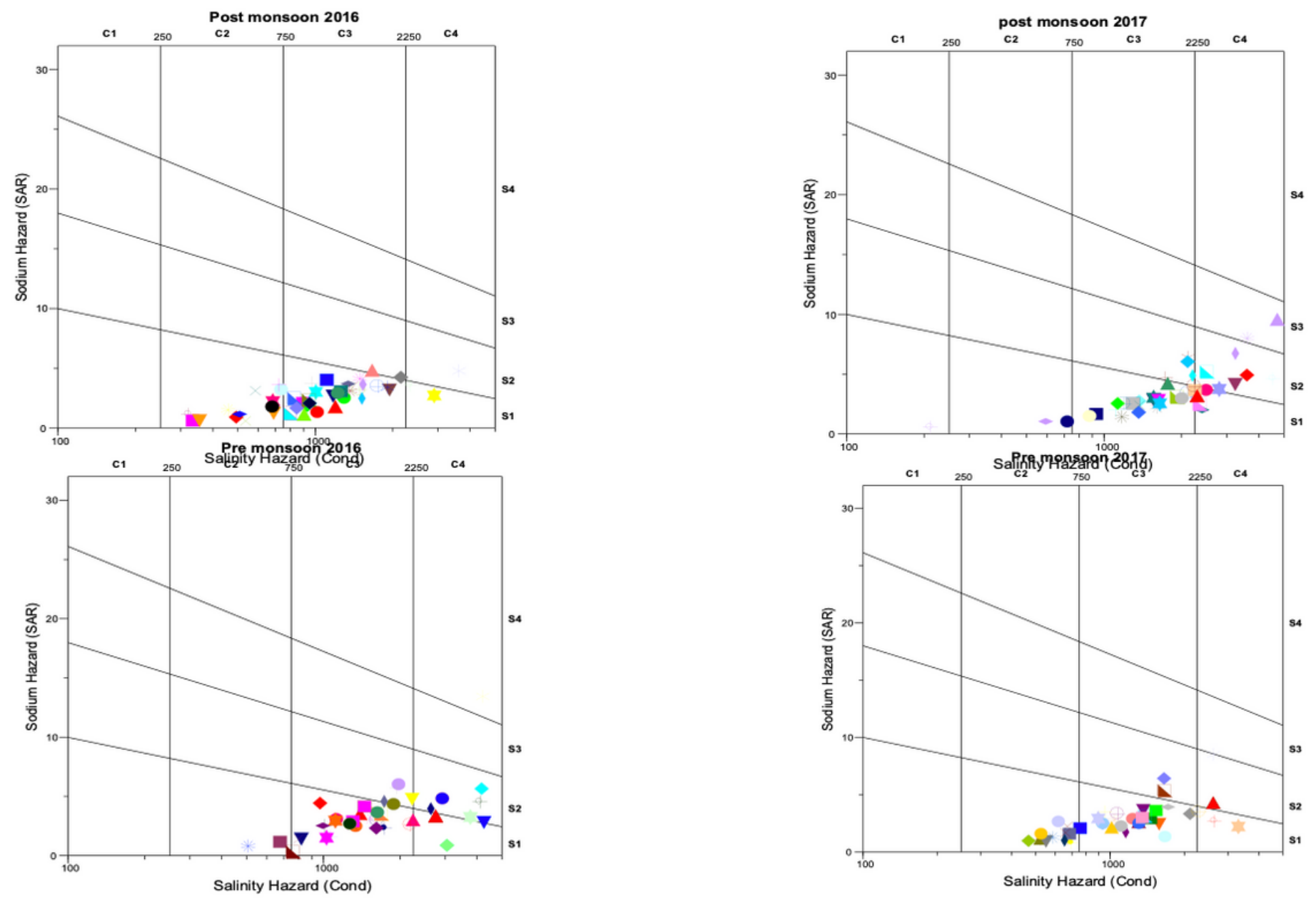

Figure 6

Wilcox diagram for post and pre-monsoon. 

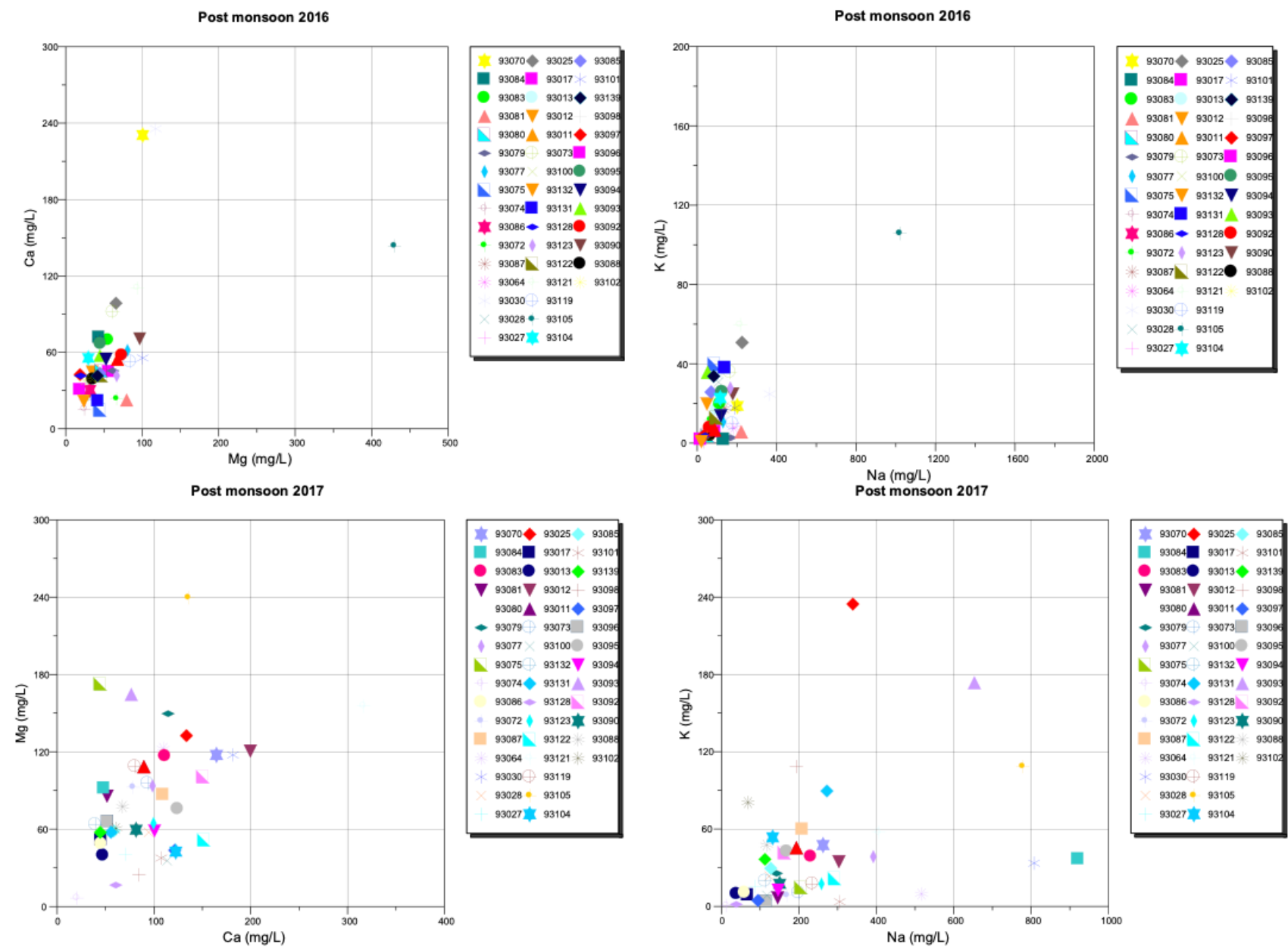

Figure 7

Scatter diagram for post-monsoon. 

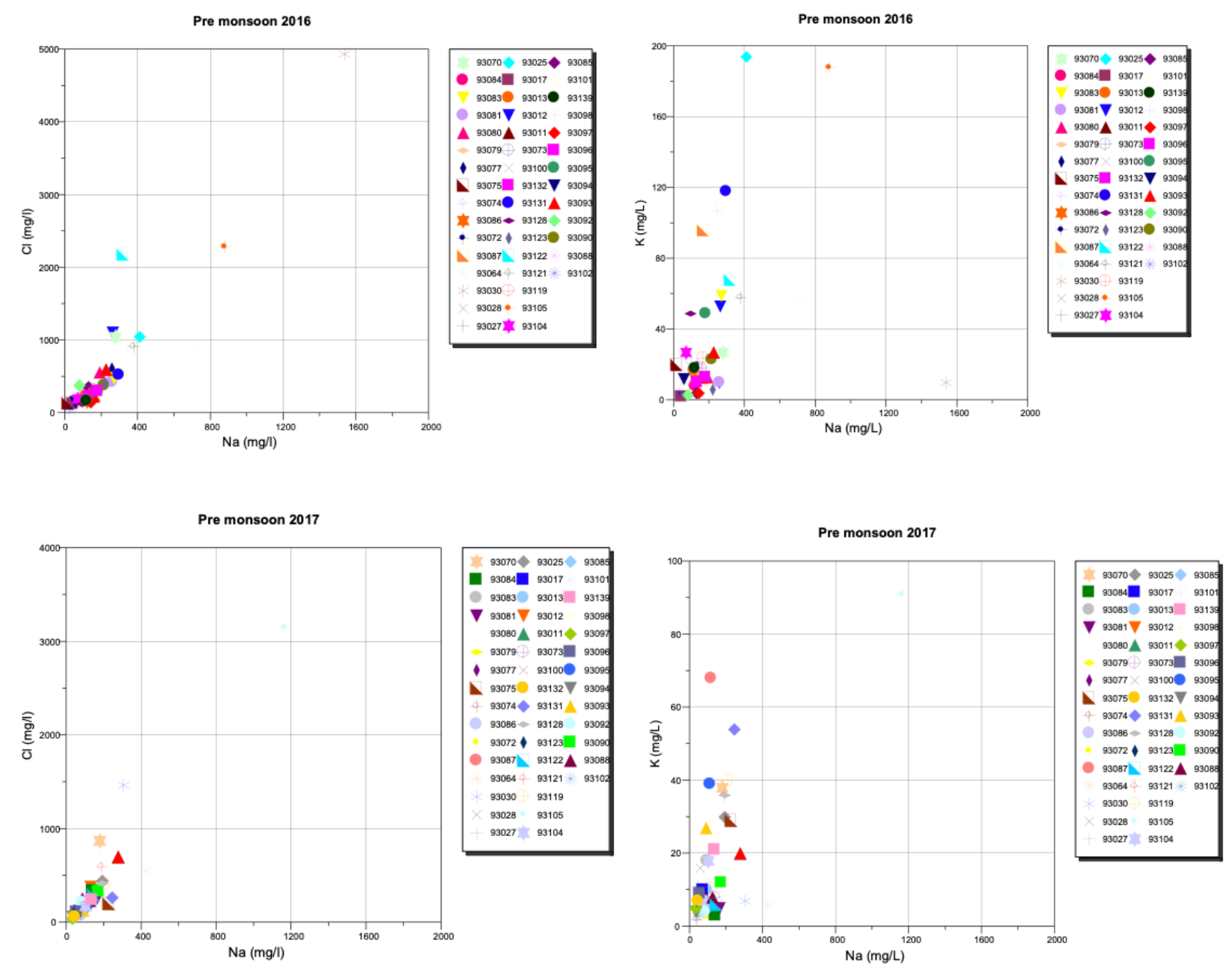

Figure 8

Scatter diagram for pre-monsoon season. 


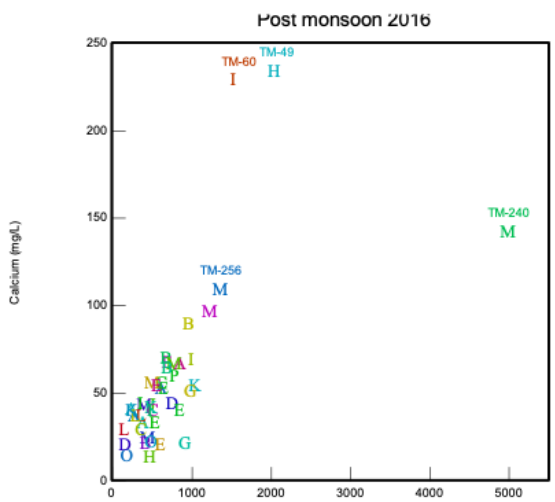

\begin{tabular}{|c|}
\hline Legen \\
\hline $\mathrm{A} \mathrm{TM}-1$ \\
\hline M TM-B \\
\hline $\begin{array}{l}\mathrm{M} T \mathrm{TM}-13 \\
3 \mathrm{TM}-18\end{array}$ \\
\hline M TM-.23 \\
\hline B TM-29 \\
\hline \\
\hline H TM-49 \\
\hline A TM.53 \\
\hline i T TM-60 \\
\hline o $\mathrm{TMM}-66$ \\
\hline $\mathrm{B} \mathrm{TM}-70$ \\
\hline o TM-BO \\
\hline $\mathrm{H} T \mathrm{TM-B2}$ \\
\hline $\mathrm{P} T \mathrm{MM}-86$ \\
\hline D TM-97 \\
\hline DM-101 \\
\hline C TM-108 \\
\hline $\mathrm{E} T \mathrm{TM}-113$ \\
\hline B $\mathrm{TM}-122$ \\
\hline $\mathrm{K} T \mathrm{TM}-125$ \\
\hline $\mathrm{C} T \mathrm{M}-136$ \\
\hline A TM- \\
\hline $\mathrm{L}, \mathrm{TM}-153$ \\
\hline $\mathrm{TM}-159$ \\
\hline $\begin{array}{l}\text { c TM-166 } \\
\text { 19 More. }\end{array}$ \\
\hline
\end{tabular}

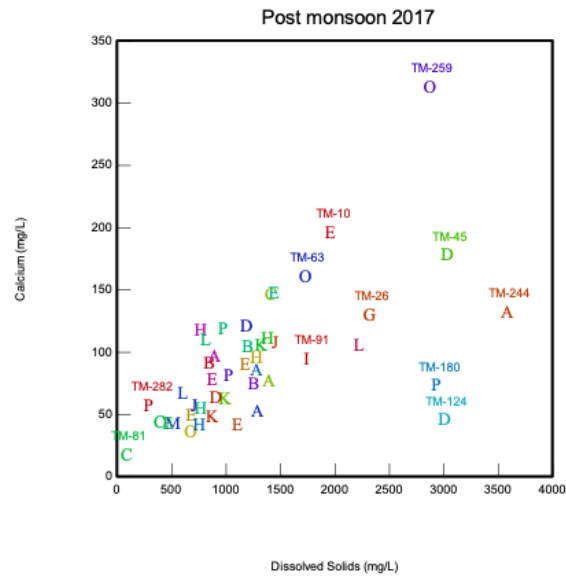

\begin{tabular}{|c|c|}
\hline \\
\hline \\
\hline \\
\hline \multirow{2}{*}{\multicolumn{2}{|c|}{$\begin{array}{l}\text { Legend } \\
\text { A } T M-5 \\
\text { E } T M-10 \\
\text { C } T M-15 \\
\text { M } T M-20 \\
\text { G } T M-26\end{array}$}} \\
\hline & \\
\hline & \\
\hline \multirow{2}{*}{\multicolumn{2}{|c|}{$\begin{array}{l}\text { B TM-39 } \\
\text { D TM-45 } \\
\text { L. TM-57 }\end{array}$}} \\
\hline & \\
\hline \multirow{2}{*}{\multicolumn{2}{|c|}{$\begin{array}{l}T M-63 \\
\text { o } \\
\text { в } \quad T M-68\end{array}$}} \\
\hline \multirow{3}{*}{\multicolumn{2}{|c|}{$\begin{array}{l}\text { E TM-75 } \\
\text { C TM-81 }\end{array}$}} \\
\hline & \\
\hline \\
\hline & \\
\hline \\
\hline & \\
\hline \multirow{2}{*}{\multicolumn{2}{|c|}{$\begin{array}{l}\text { J TM-118 } \\
\text { D TM-124 }\end{array}$}} \\
\hline & \\
\hline \multirow{3}{*}{\multicolumn{2}{|c|}{$\begin{array}{l}\text { H } T M-130 \\
\text { E TM-139 }\end{array}$}} \\
\hline & \\
\hline & \\
\hline \multirow{2}{*}{\multicolumn{2}{|c|}{$\begin{array}{l}\mathrm{K} \text { TM-148 } \\
\text { D TM-156 } \\
\text { E TM-162 }\end{array}$}} \\
\hline & \\
\hline \multicolumn{2}{|l|}{$\begin{array}{l}\text { c TM-171 } \\
19 \text { More... }\end{array}$} \\
\hline
\end{tabular}
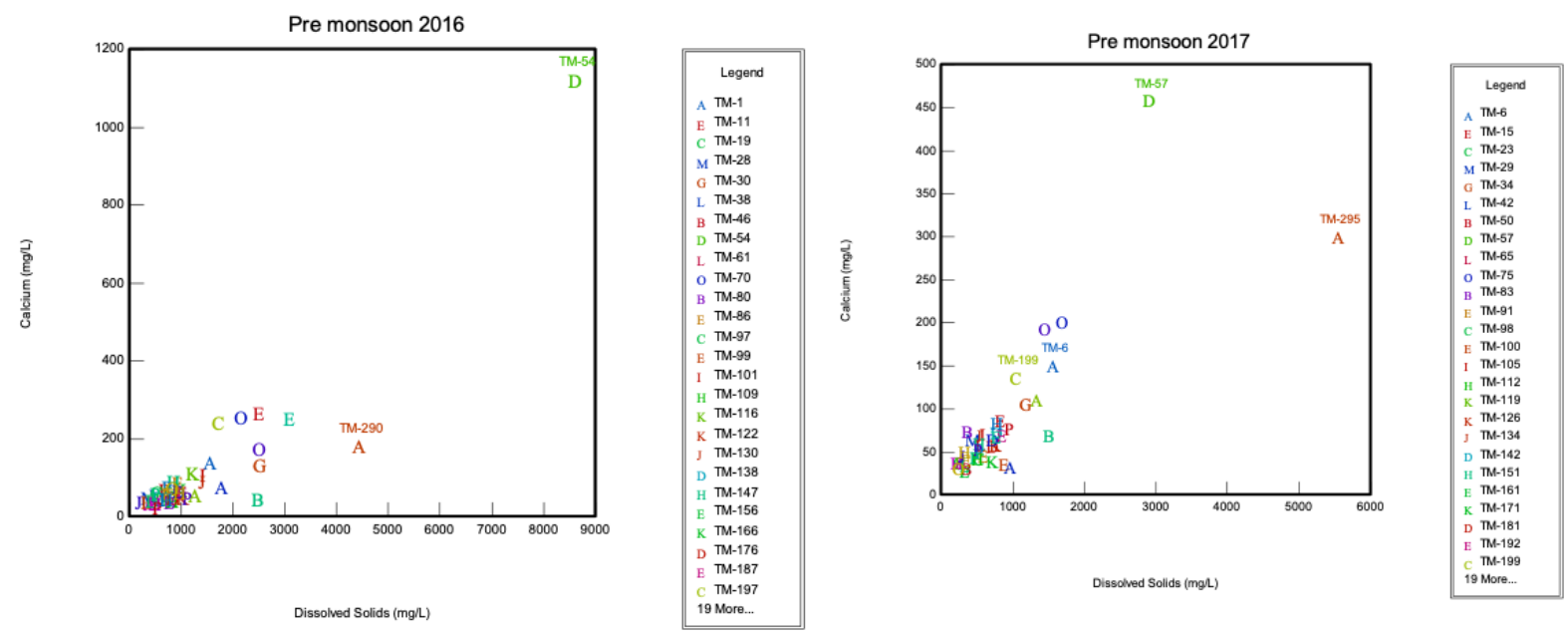

\section{Figure 9}

Cross plot representation of collected samples. 

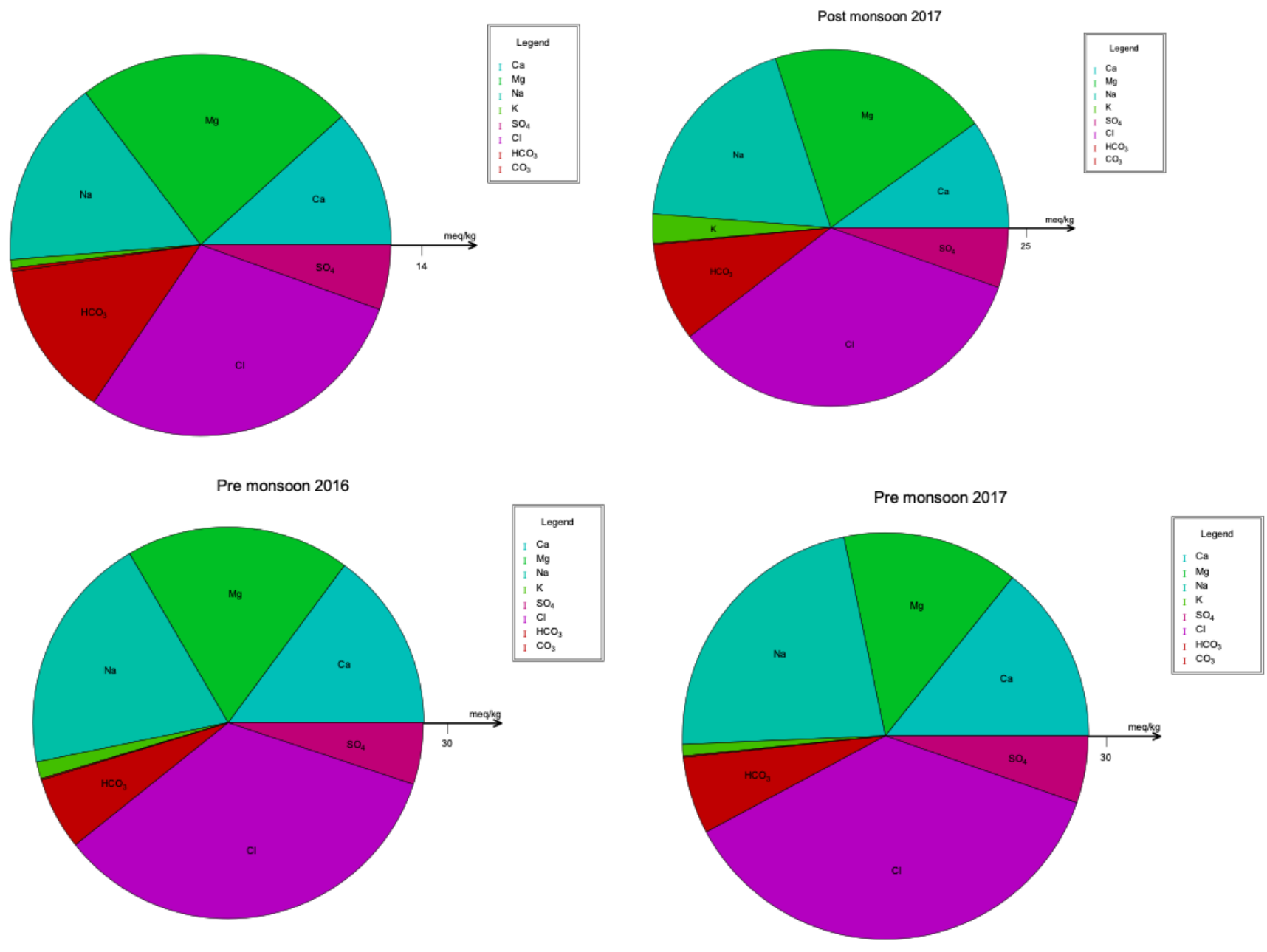

Figure 10

Pie chart for post and pre-monsoon 

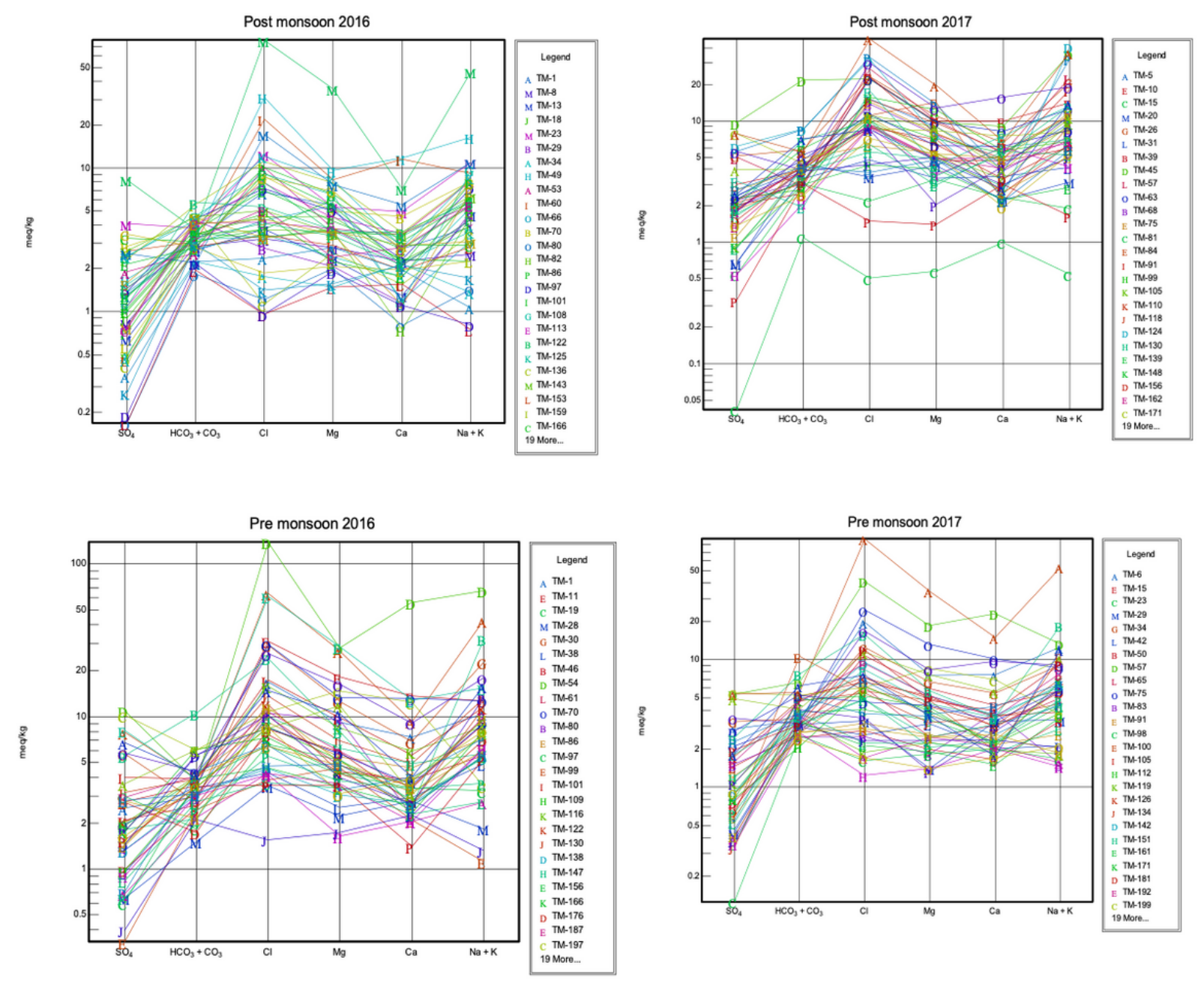

Figure 11

Schoeller diagram for post and pre-monsoon 
Post monsoon 2016

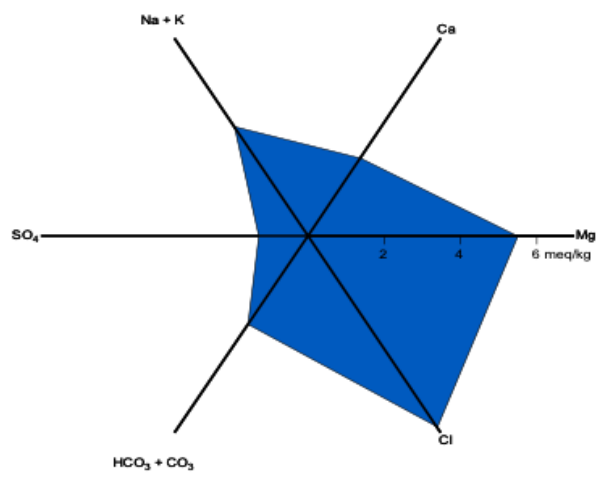

Pre monsoon 2016

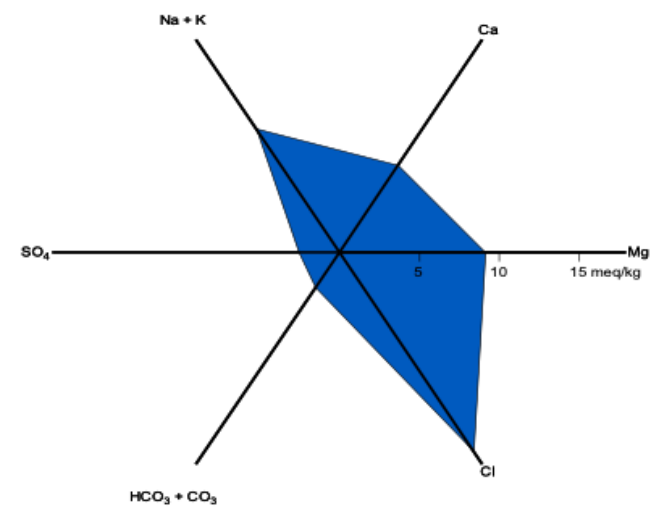

Post monsoon 2017

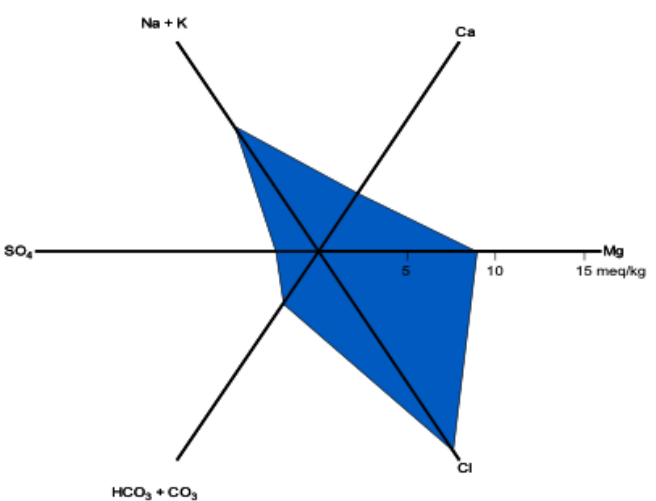

Pre monsoon 2017

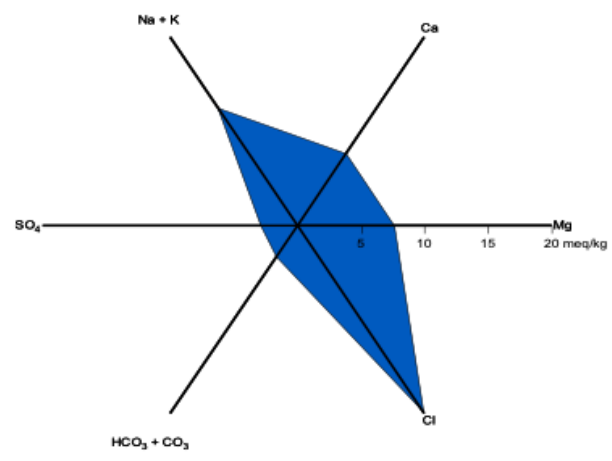

\section{Figure 12}

Radial plot for post and pre-monsoon 